Review

\title{
Dye Sensitizers for Photodynamic Therapy
}

\section{Alexandra B. Ormond * and Harold S. Freeman}

Fiber and Polymer Science Program, North Carolina State University, Raleigh, NC 27695-8301, USA; E-Mail: hfreeman@ncsu.edu

* Author to whom correspondence should be addressed; E-Mail: abpolian@ncsu.edu; Tel.: +1-919-515-6552; Fax: +1-919-515-3057.

Received: 31 January 2013; in revised form: 20 February 2013 / Accepted: 22 February 2013 / Published: 6 March 2013

\begin{abstract}
Photofrin ${ }^{\circledR}$ was first approved in the 1990 s as a sensitizer for use in treating cancer via photodynamic therapy (PDT). Since then a wide variety of dye sensitizers have been developed and a few have been approved for PDT treatment of skin and organ cancers and skin diseases such as acne vulgaris. Porphyrinoid derivatives and precursors have been the most successful in producing requisite singlet oxygen, with Photofrin ${ }^{\circledR}$ still remaining the most efficient sensitizer (quantum yield $=0.89$ ) and having broad food and drug administration (FDA) approval for treatment of multiple cancer types. Other porphyrinoid compounds that have received approval from US FDA and regulatory authorities in other countries include benzoporphyrin derivative monoacid ring $\mathrm{A}$ (BPD-MA), meta-tetra(hydroxyphenyl)chlorin (m-THPC), $N$-aspartyl chlorin e6 (NPe6), and precursors to endogenous protoporphyrin IX (PpIX): 1,5-aminolevulinic acid (ALA), methyl aminolevulinate (MAL), hexaminolevulinate (HAL). Although no non-porphyrin sensitizer has been approved for PDT applications, a small number of anthraquinone, phenothiazine, xanthene, cyanine, and curcuminoid sensitizers are under consideration and some are being evaluated in clinical trials. This review focuses on the nature of PDT, dye sensitizers that have been approved for use in PDT, and compounds that have entered or completed clinical trials as PDT sensitizers.
\end{abstract}

Keywords: photodynamic therapy; photosensitizers; porphyrins; clinical trials; target organs 


\section{Introduction}

In the medical arena, the treatment of skin diseases with the aid of light has been performed since $1400 \mathrm{BC}$ [1], and this technology is now known as phototherapy. Phototherapy employs either UV or visible light, with or without a photosensitizer - A molecule capable of absorbing light energy and transferring that energy to adjacent molecules. When a photosensitizer is not used, phototherapy is mainly employed in dermatology to treat vitamin D deficiency, neonatal jaundice, psoriasis, eczema, vitiligo, polymorphous light eruption, cutaneous T-cell lymphoma, lichen planus, and even to ease the symptoms of Parkinson's disease [2-4].

Photochemotherapy, on the other hand, utilizes a photosensitizer, usually of the psoralen series (1-3; Figure 1), in tandem with UVA (300-400 nm) radiation [5]. Treatments involve psoriasis, atopic dermatitis, seborrheic dermatitis, eczema, alopecia areata, chronic cutaneous graft-versus-host disease, HIV-associated dermatoses, histiocytosis, lichen planus, mycosis fungoids, polymorphous light eruption, pityriasis lichenoides, lymphamatoid papulosis, prurigo, palmar and plantar pustulosis, and vitiligo [6].

Figure 1. Examples of psoralen photosensitizers.<smiles>COc1c2ccoc2cc2oc(=O)ccc12</smiles>

1

5-Methoxypsoralen<smiles>COc1c2occc2cc2ccc(=O)oc12</smiles>

2

8-Methoxypsoralen<smiles>Cc1cc2cc3c(C)cc(=O)oc3c([N+](=O)[O-])c2o1</smiles>

3

Trioxsalen

Figure 2. Basic structures of porphyrinoid photosensitizers.

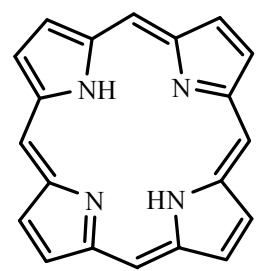

Porphyrin

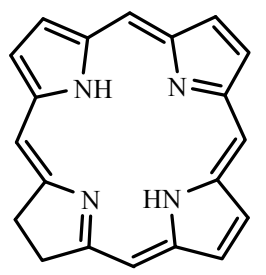

Chlorin

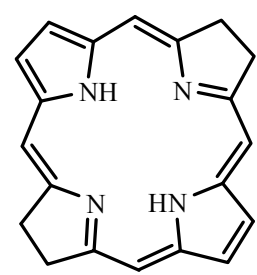

Bacteriochlorin

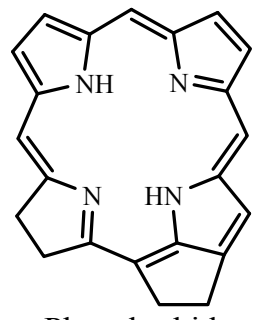

Pheophorbide

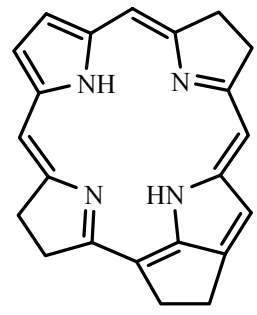

Bacteriopheophorbide
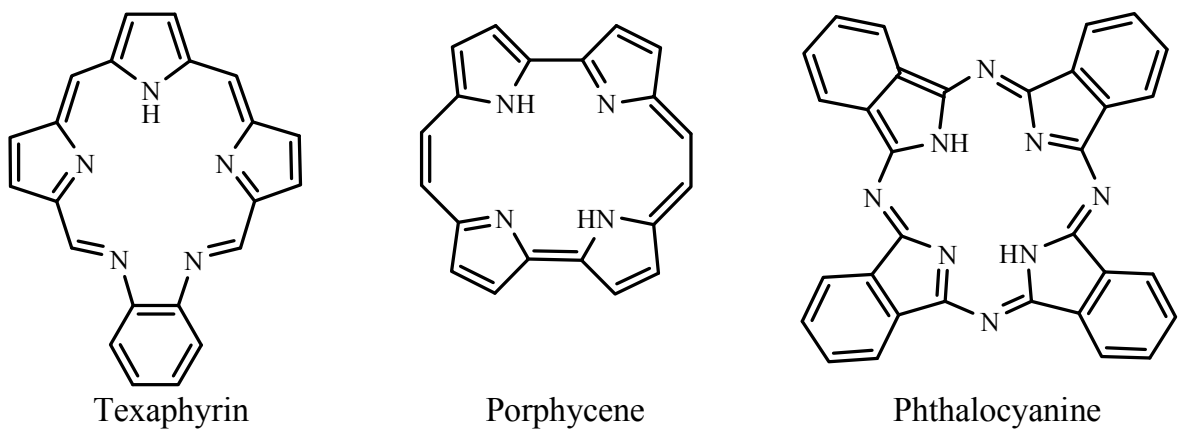

Porphycene

Photodynamic therapy (PDT) is a type of photochemotherapy and requires the presence of light, a photosensitizer, and molecular oxygen for treatments [7]. The combination of photosensitizer and light 
as therapeutic agents was first introduced in the early 1900s [8] but it was not until the 1990s that the food and drug administration (FDA) approved PDT using a pure form of Photofrin ${ }^{\circledR}$. Suitable dye sensitizers for PDT are mainly porphyrinoid compounds, including chlorins, bacteriochlorins, phthalocyanines, and related structures [9]. These compounds have extended conjugation and absorb light in the visible region, which makes them colored compounds or dyes. This review covers porphyrinoid and non-porphyrin dye photosensitizers. The porphyrinoid photosensitizers reviewed are porphyrins, chlorins, pheophorbides, bacteriopheophorbides, texaphyrins, and phthalocyanines. The non-porphyrins are anthraquinones, phenothiazines, xanthenes, cyanines, and curcuminoids. Figure 2 shows the basic structures of porphyrinoid compounds.

\subsection{Photodynamic Action and Mechanisms}

PDT involves the use of light exposures to transform a sensitizer from the ground state $\left(\mathrm{S}_{0}\right)$ to the first excited state $\left(\mathrm{S}_{1}\right)$. The sensitizer must be sufficiently stable in the excited state to undergo intersystem crossing to the triplet excited state $\left(\mathrm{T}_{1}\right)$, a longer-lived state. At this stage, two reaction processes involving molecular oxygen can take place. In the first process, Type I, hydrogen abstraction or electron transfer between an excited sensitizer and an adjacent sensitizer molecule occurs, with ion radical formation. The resultant radical can react with ground state oxygen $\left({ }^{3} \mathrm{O}_{2}\right)$ to produce reactive oxygen species (ROS) such as superoxide anion $\left(\mathrm{O}_{2}^{-\bullet}\right)$, hydrogen peroxide $\left(\mathrm{H}_{2} \mathrm{O}_{2}\right)$, and hydroxyl radical $\left(\mathrm{OH}^{*}\right)$ [9]. In the second process, Type II, energy from $\mathrm{T}_{1}$ is transferred directly to ${ }^{3} \mathrm{O}_{2}$, exciting it to singlet oxygen $\left({ }^{1} \mathrm{O}_{2}\right)$ as illustrated in Figure 3. Energy transfer to ${ }^{3} \mathrm{O}_{2}$ can occur only if a sensitizer is in the same triplet state multiplicity, or occupies $\mathrm{T}_{1}$, as ground state oxygen.

Figure 3. Modified Jablonski diagram showing Type II sensitization process.

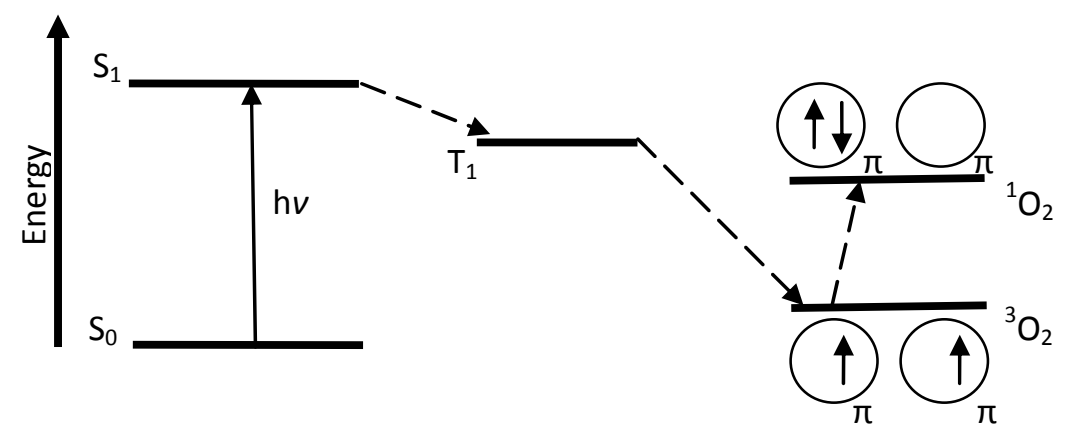

Table 1 lists the series of reactions that occur during PDT. PS is the photosensitizer, ${ }^{1}$ PS is PS in ground state, ${ }^{1} \mathrm{PS} *$ and ${ }^{3} \mathrm{PS} *$ are PS in singlet excited and triplet excited states, respectively, and D is an electron donor molecule, e.g., NADH, cysteine, etc. [9]. The reaction between ${ }^{3} \mathrm{PS} *$ and ${ }^{1} \mathrm{PS}$ leads to $\mathrm{PS}$ anion and cation radicals, $\mathrm{PS}^{-}$and $\mathrm{PS}^{+\bullet}$, respectively. D can react with ${ }^{3} \mathrm{PS} *$ to produce more $\mathrm{PS}^{-\bullet}$ and oxidized donor $\left(\mathrm{D}^{+}\right)$. The superoxide anion, $\mathrm{O}_{2}^{-}$, is shown to form via two routes: (1) $\mathrm{PS}^{-\bullet}$ electron exchange with oxygen and (2) electron transfer of ${ }^{3} \mathrm{PS}^{*}$ with oxygen. $\mathrm{O}_{2}^{-\bullet}$ formation from ${ }^{3} \mathrm{PS}^{*}$, however, competes with the production of singlet oxygen (type II). Also, two superoxide anion molecules can combine with protons to produce hydrogen peroxide. The subsequent steps include reduction of $\mathrm{Fe}^{3+}$ by $\mathrm{O}_{2}^{-\bullet}$, and $\mathrm{Fe}^{2+}$ reaction with hydrogen peroxide to form a hydroxyl radical. This species can interfere with the biological functions of nucleic acids, fatty acids, and certain amino acids [9]. 
Type II process involves only a limited number of molecules because the reacting species must have triplet state multiplicity [8]. Since ground state oxygen $\left({ }^{3} \mathrm{O}_{2}\right)$ is already in its triplet state, the reaction between triplet excited state of a photosensitizer and ${ }^{3} \mathrm{O}_{2}$ is possible. Type I and Type II processes occur at the same time; however, Type II is the dominant process in PDT and it is catalytic.

Table 1. Reactions occurring during photodynamic action [9].

\begin{tabular}{cccc}
\hline Excitation & ${ }^{1} \mathrm{PS}+\mathrm{h} v \rightarrow{ }^{1} \mathrm{PS}^{*} \rightarrow{ }^{3} \mathrm{PS}^{*}$ & \\
\hline Photoprocess & Reaction & & Product \\
\hline Type I & ${ }^{3} \mathrm{PS}^{*}+{ }^{1} \mathrm{PS}$ & $\rightarrow$ & $\mathrm{PS}^{-\bullet}+\mathrm{PS}^{+\bullet}$ \\
& ${ }^{3} \mathrm{PS}^{*}+\mathrm{D}$ & $\rightarrow$ & $\mathrm{PS}^{-\bullet}+\mathrm{D}^{+}$ \\
& $\mathrm{PS}^{-\bullet}+\mathrm{O}_{2}$ & $\rightarrow$ & ${ }^{1} \mathrm{PS}+\mathrm{O}_{2} \cdot$ \\
& ${ }^{3} \mathrm{PS}^{*}+\mathrm{O}_{2}$ & $\rightarrow$ & $\mathrm{PS}^{+\bullet}+\mathrm{O}_{2} \cdot$ \\
& $2 \mathrm{O}_{2}^{-\bullet}+2 \mathrm{H}^{+}$ & $\rightarrow$ & $\mathrm{O}_{2}+\mathrm{H}_{2} \mathrm{O}_{2}$ \\
& $\mathrm{Fe}^{3+}+\mathrm{O}_{2}^{-\bullet}$ & $\rightarrow$ & $\mathrm{Fe}^{2+}+\mathrm{O}_{2}$ \\
& $\mathrm{Fe}^{2+}+\mathrm{H}_{2} \mathrm{O}_{2}$ & $\rightarrow$ & $\mathrm{O}_{2}+\mathrm{OH}^{-}+\mathrm{OH}^{\bullet}$ \\
\hline Type II & ${ }^{3} \mathrm{PS}^{*}+{ }^{3} \mathrm{O}_{2}$ & $\rightarrow$ & ${ }^{1} \mathrm{PS}+{ }^{1} \mathrm{O}_{2}$ \\
\hline
\end{tabular}

\subsubsection{Photodynamic Action in the Body}

During PDT, a sensitizer can be administered intravenously, intraperitoneally, or topically, and it selectively localizes in a tumor due to physiological differences in the tumor and healthy tissue [10,11]. Localization into cancer cells and achieving a maximum tumor-to-normal cell concentration ratio can take 3 to $96 \mathrm{~h}$, depending on the photosensitizer and the tumor. Following localization, fluorescence from the sensitizer can be used to diagnose and detect the tumor. Irradiation at a wavelength specific to the photosensitizer produces singlet oxygen, which reacts with and destroys the tumor (cf. Figure 4). Cell destruction can occur in several ways, one of which is damage to the vasculature by erythema or edema, another is direct cell destruction by apoptosis or necrosis [12,13]. Chances of skin photosensitivity are high, even though the dye has greater affinity for tumor tissue. This effect requires patients to limit sunlight exposure to eyes and skin up to thirty days or longer following treatment [14], depending on the sensitizer.

Figure 4. Schematic representation of photodynamic therapy (PDT) treatment of a malignant tumor [7].

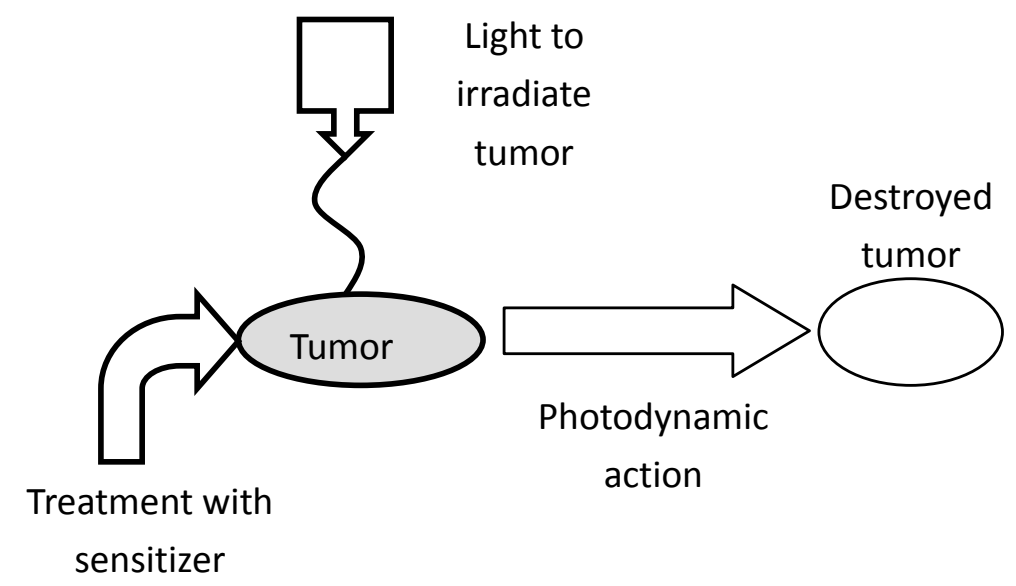




\subsection{Light and Oxygen in PDT}

Light can be delivered via an argon or copper pumped dye laser coupled to an optical fiber, a double laser consisting of KTP (potassium titanyl phosphate)/YAG (yttrium aluminum garnet) medium, LED (light emitting diode), or a solid state laser [13]. For PDT using Photofrin ${ }^{\circledR}$ as the photosensitizer, an argon pumped dye laser coupled to an optical fiber is used and it operates at $630 \mathrm{~nm}$. At this wavelength, light penetrates only 2 to $3 \mathrm{~mm}$ into the tissue. The ideal photosensitizer is activated by light absorption at 700-800 nm, and provides light penetration of 5 to $6 \mathrm{~mm}$ depths [12]. At low wavelengths, scattering and absorption of light by human tissue is high, and at wavelengths far into the red or near infrared regions, negative effects are also possible. One negative effect is photobleaching [2]. Photobleaching causes dye sensitizer modification with or without chromogen destruction, as well as loss of fluorescence [15]. In the case of Photofrin ${ }^{\circledR}$, a decrease in oxidation potential and photostability occurs [2]. Another consequence of light absorption at higher wavelength is inefficient energy transfer from $T_{1}$ of the photosensitizer during singlet oxygen generation [15]. With appropriate energy transfer, ground state oxygen is converted to singlet oxygen (cf. Figure 5). This transition requires $94 \mathrm{~kJ} \mathrm{~mol}^{-1}\left(22.5 \mathrm{kcal} \mathrm{mol}^{-1}\right)$ or $1270 \mathrm{~nm}$; thus, triplet states of photosensitizers extending beyond this region will not have enough energy to produce singlet oxygen.

The lifetime of singlet oxygen is very short due to its reactivity. In $\mathrm{H}_{2} \mathrm{O}$, the lifetime is $3.5 \mu \mathrm{s}$, in $\mathrm{D}_{2} \mathrm{O}$ it is $68 \mu \mathrm{s}$ [16], in organic solvents its lifetime is $10-100 \mu \mathrm{s}$ [8], and in lipids it is $50-100 \mu \mathrm{s}$ [17]. The lifetime decreases dramatically to $0.2 \mu \mathrm{s}$ inside cells, due to high reactivity with biological substances [9]. Rapid reactivity and a short lifetime limit the singlet oxygen distribution in cells. Thus, PDT treatments are localized at the point of ${ }^{1} \mathrm{O}_{2}$ generation and are only about $10 \mathrm{~nm}$ in diameter (thickness of a cell membrane) [8,18].

Figure 5. Triplet $\left({ }^{3} \mathrm{O}_{2}\right)$ and singlet $\left({ }^{1} \mathrm{O}_{2}\right)$ states of oxygen.
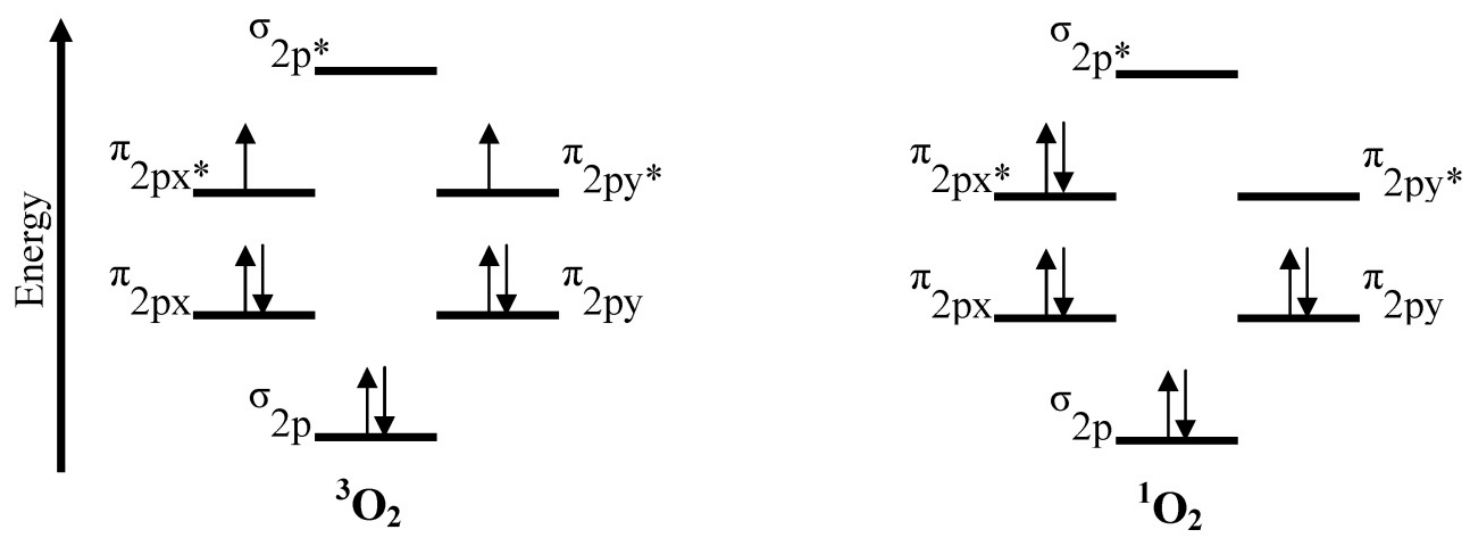

\subsection{Photosensitizer Distribution in Tissues}

Inside the body, photosensitizers probably interact with tumors via low-density lipoprotein (LDL) receptors [19]. Cancer cells have elevated levels of LDL receptors; thus, endocytosis of LDL-photosensitizer complex is preferred by malignant cells [20]. Additionally, a high fraction of tumor-associated macrophages is found in these cells, with photosensitizer levels also high in these areas [21,22]. Further selective uptake of dye photosensitizer by tumor cells is possibly due to lower 
intracellular $\mathrm{pH}$, leaky microvasculature and poor lymphatic drainage by tumors, and large amounts of collagen [17].

Photosensitizer solubility is another important factor in its distribution and location inside tumor cells. Hydrophobic compounds and their aggregates bind to LDL while hydrophilic species bind to albumin and globulins [22,23]. Accumulation of photosensitizers in the cell organelles also depends on the charge of the sensitizer. Cationic compounds, e.g., iminium salts, collect in mitochondria, while anionic species, e.g., sulfonated and carboxylated compounds, are found in lysosomes [22,23]. Dye sensitizers with one or two anionic charges localize in the perinuclear region, vesicles of the cell, and lysosomes, providing multiple sites of photosensitizer accumulation [24,25]. While water solubility is important for bioavailability of the sensitizer, lipophiliciy is important for diffusion through lipid barriers and localization in endocellular cites [26].

\section{Photosensitizer Types}

Photofrin $^{\circledR}$ (porfimer sodium), the first FDA approved PDT sensitizer, belongs to the porphyrin family and is a hematoporphyrin derivative $(\mathrm{HpD})$. Hematoporphyrin $(\mathrm{Hp})$ was produced by Scherer in 1841 by removing iron from blood (Heme) and then treatment with water [11]. HpD (4) was developed by treating $\mathrm{Hp}$ with $\mathrm{AcOH} / \mathrm{H}_{2} \mathrm{SO}_{4}$ to give a mixture of monomers, dimers, and oligomers, linked by ether, ester, and carbon-carbon bonds [27]. The types of steps associated with its synthesis are illustrated in Figure $6[9,28]$. Removal of monomers from $\mathrm{HpD}$ by heating the reaction mixture in the last step of the synthesis until hydrolysis is complete led to Photofrin ${ }^{\circledR}$, a product consisting of ether-linked dimers and trimers [11,29].

\subsection{Photosensitizer Properties}

The ideal PDT photosensitizer has the following characteristics [30]:

(a) available in pure form, of known chemical composition;

(b) synthesizable from available precursors and easily reproduced;

(c) high singlet oxygen quantum yield $\left(\Phi_{\Delta}\right)$;

(d) strong absorption in the red region of the visible spectrum $(680-800 \mathrm{~nm})$ with a high extinction coefficient $\left(\varepsilon_{\max }\right)$, e.g., $50,000-100,000 \mathrm{M}^{-1} \mathrm{~cm}^{-1}$;

(e) effective accumulation in tumor tissue and possession of low dark toxicity for both photosensitizer and its metabolites;

(f) stable and soluble in the body's tissue fluids, and easy delivery to the body via injection or other methods;

(g) excreted from the body upon completion of treatment.

\subsection{First Generation Photosensitizers}

Photofrin $^{\circledR}$ and $\mathrm{HpD}$ are known as first generation photosensitizers mainly because they exist as complex mixtures of monomeric, dimeric, and oligomeric structures, and the intensity of light absorption at the maximum wavelength $\left(\varepsilon_{\max }\right)$ of Photofrin ${ }^{\circledR}$ is low $\left(\varepsilon_{\max }\right.$ at $\left.630 \mathrm{~nm} 3000 \mathrm{M}^{-1} \mathrm{~cm}^{-1}\right)$. This low $\varepsilon_{\max }$ means that Photofrin ${ }^{\circledR}$ absorbs light weakly at $630 \mathrm{~nm}$. The higher the $\varepsilon_{\max }$ value the 
greater the potential photodynamic effect. Also, at $630 \mathrm{~nm}$, the effective tissue penetration of light is small, 2-3 mm, limiting treatment to surface tumors. Its long-term skin phototoxicity lasts six to ten weeks, meaning sunlight and strong artificial light exposure must be avoided during this period. Although Photofrin ${ }^{\circledR}$ has its weaknesses, it gives a high singlet oxygen quantum yield, $\Phi_{\Delta}=0.89$, which indicates efficient generation of ${ }^{1} \mathrm{O}_{2}$ per photon absorbed. Photofrin ${ }^{\circledR}$ is also safe and was approved in 1993 by Canada for treatment of bladder cancer and by the US FDA for treating esophageal cancer in 1995, lung cancer in 1998, and Barrett's esophagus in 2003 [31]. Photofrin ${ }^{\circledR}$ treatment extends to head, neck, abdominal, thoracic, brain, intestinal, skin, breast, and cervical cancer [30].

Other types of hematoporphyrin derivatives are Photogem ${ }^{\circledR}$ and Photosan- $3^{\circledR}$. Photogem ${ }^{\circledR}$ consists of monomers, dimers, and oligomers [32] and has been approved for use in clinical applications in Russia and Brazil [33]. Photosan- $3^{\circledR}$ has been approved for clinical use in the EU [34].

Figure 6. Synthesis of hematoporphyrin derivative (HpD) from heme.

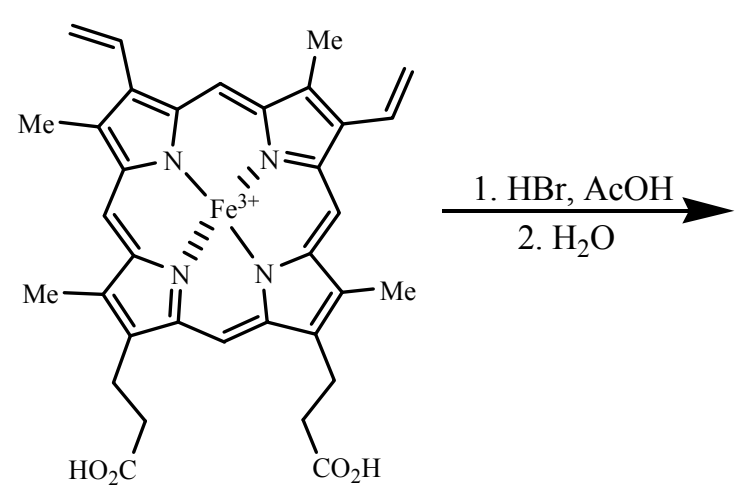

Heme

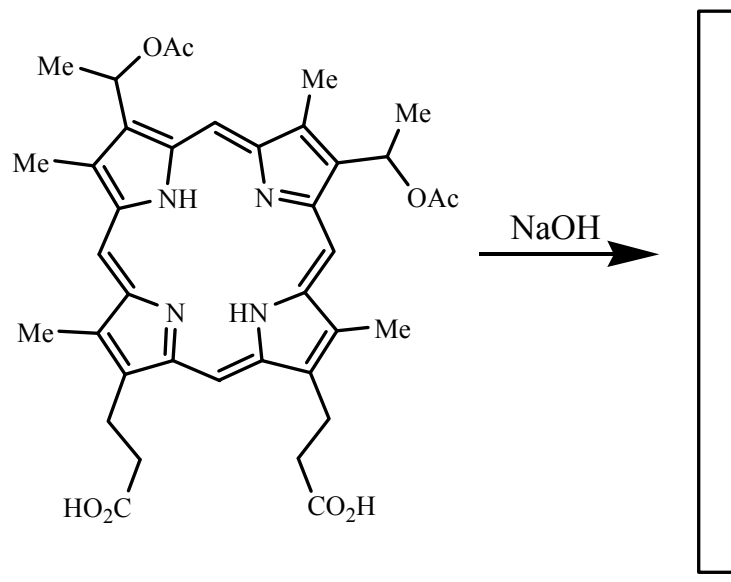

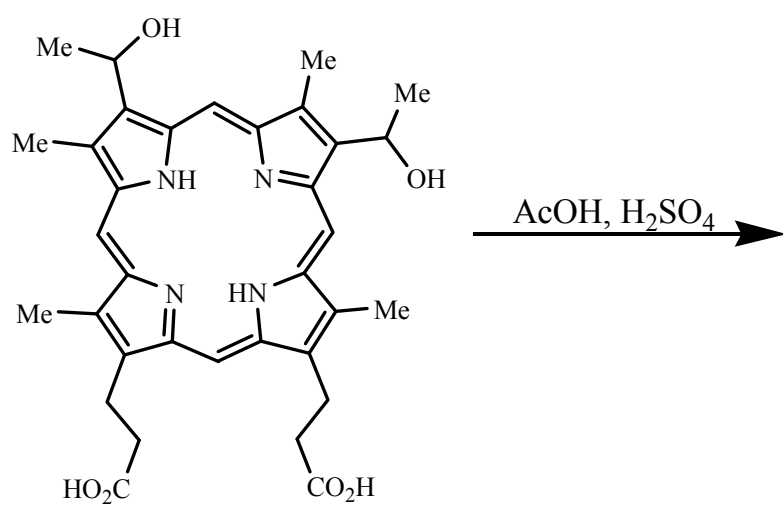

Hp

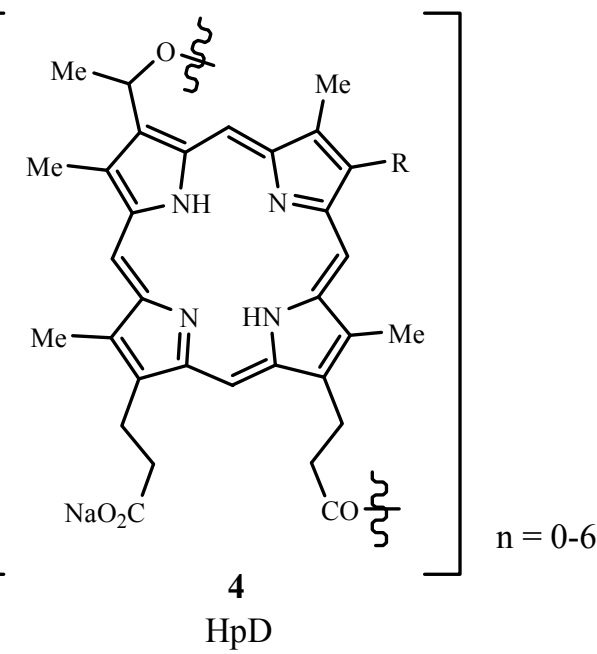

\subsection{Second Generation Photosensitizers}

The properties of unfavorable skin phototoxicity, low absorption in the red region of the visible spectrum, as well as complex mixtures arising from the method of synthesis were targeted for improvement with second generation photosensitizers. 


\subsubsection{Porphyrins}

From the porphine family, meta-tetra(hydroxyphenyl)porphyrin ( $m$-THPP, 5), the meta isomer of 5,10,15,20-tetra(hydroxyphenyl)porphyrin, and 5,10,15,20-tetrakis(4-sulfanatophenyl)-21H,23H-porphyrin $\left(\mathrm{TPPS}_{4}, 6\right)$ are second generation PDT sensitizers (cf. Figure 7). m-THPP, however, caused skin phototoxicity, but not as severely as the ortho isomer. $m$-THPP was 25 to 30 times as potent as HpD in tumor photonecrosis when irradiated at $648 \mathrm{~nm}$ [2]. TPPS 4 exhibited lower photochemical efficiency than meso-substituted porphyrins containing fewer sulfonate groups [27,30]. The irradiation of TPPS $_{4}$ at $645 \mathrm{~nm}$ with an argon-pumped dye laser showed it to be a potential candidate for treating basal cell carcinoma [35].

Figure 7. Molecular structures of some second generation porphyrins.
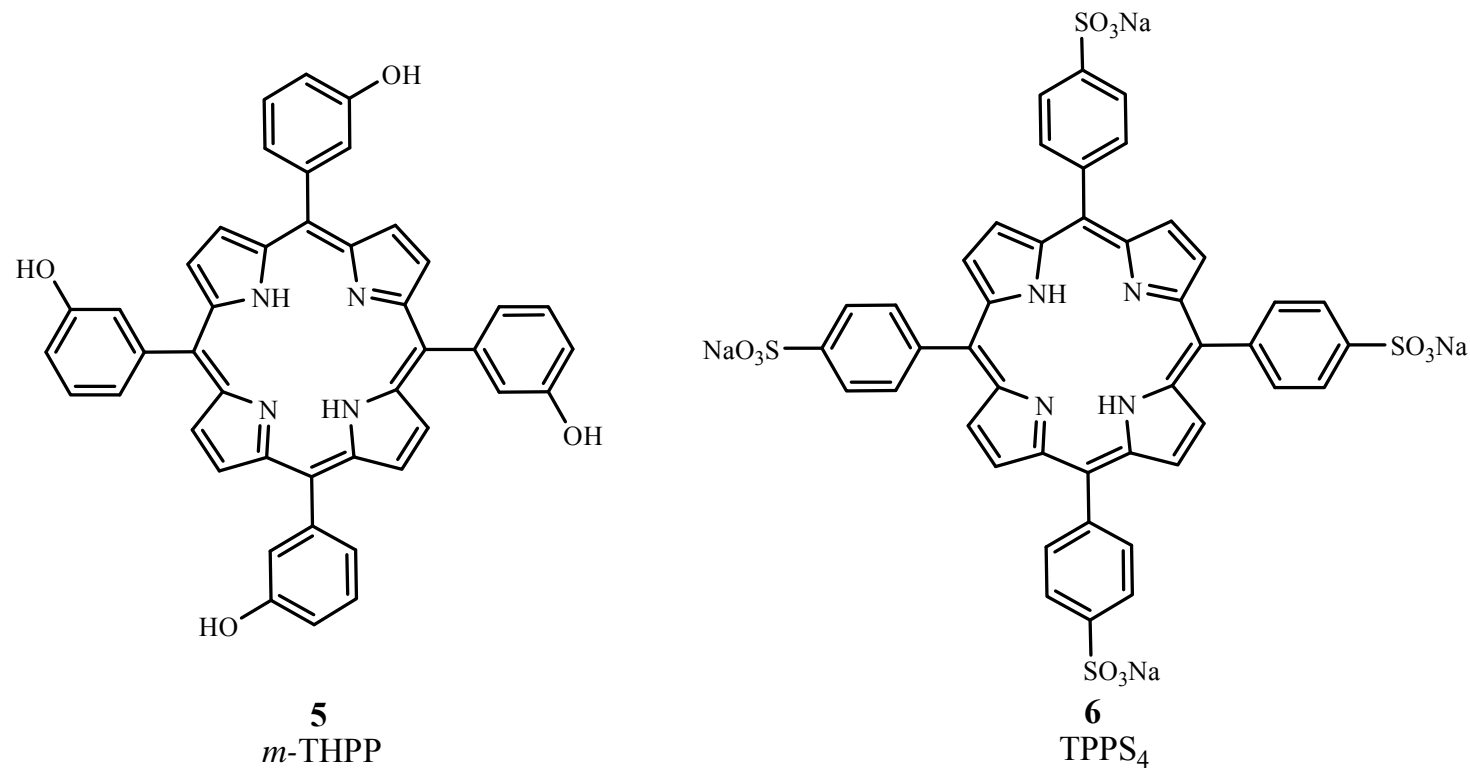

Endogenous Protoporphyrin IX (PpIX, 7) induced by exogenous 1,5-aminolevulinic acid (ALA or Levulan Kerasticks ${ }^{\circledR}, \mathbf{8}$ ) was US FDA approved for non-oncological PDT treatment of actinic keratosis in 1999 [36]. Application of ALA prodrug to skin enzymatically transforms it to PpIX photosensitizer via the heme pathway shown in Figure 8. The final step in heme formation by enzyme ferrochelatase is a rate-limiting step, and excess ALA accumulates PpIX in the mitochondria before it slowly transforms into heme [37]. While the PpIX absorption maximum is low (630 to $635 \mathrm{~nm})$, it metabolizes within 48 hours, reducing skin sensitization [38]. Its potential PDT applications extend to Bowen's disease, basal cell carcinoma, and other diseases; and ALA can be used to detect tumors in bladder, skin, lung, and gastrointestinal tract [39].

The methyl ester of ALA, methyl aminolevulinate (MAL, Metvix ${ }^{\circledR}$, or Metvixia ${ }^{\circledR}, 9$; Figure 9), was approved by the US FDA in 2004 for treatment of actinic keratosis [40]. Under the trade name Metvixia $^{\circledR}$, MAL is also used as a topical treatment and has an advantage over Levulan ${ }^{\circledR}$ due to the nature of the irradiation source. Blu- $\mathrm{U}^{\circledR}$ light was approved for use with Levulan ${ }^{\circledR}$ as the most efficient source emitting at $400 \mathrm{~nm}$, while Aktilite ${ }^{\circledR}$ was approved for Metvixia ${ }^{\circledR}$ which emits at $630 \mathrm{~nm}$ and provides deeper tissue penetration [41]. MAL is the active component in Visonac ${ }^{\circledR}$ and is being studied for acne vulgaris in Phase II trials (NCT01347879) in the US [42]. 
Hexaminolevulinate, the $n$-hexyl ester of ALA, (HAL, Hexvix ${ }^{\circledR}$, Cysview $\left.^{\circledR}, 10\right)$ was approved in 2010 by the US FDA in the diagnosis of bladder cancer [43]. HAL is converted to PpIX 50-100 times more efficiently than ALA [44]. Phase II trials are underway for treatment of cervical intraepithelial neoplasia (NCT01256424) [45], and Phase II/III trials are ongoing for genital erosive lichen planus (NCT01282515) [46].

Figure 8. Pathway for heme biosynthesis.

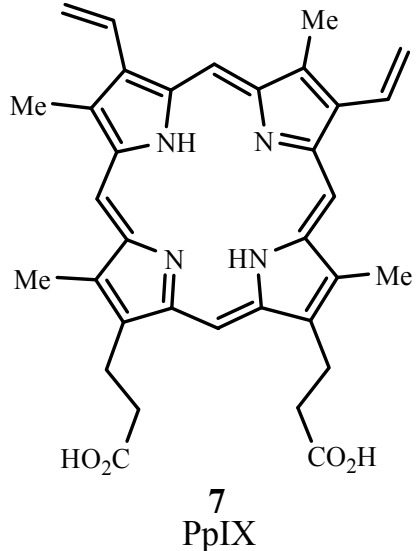

MITOCHONDRION

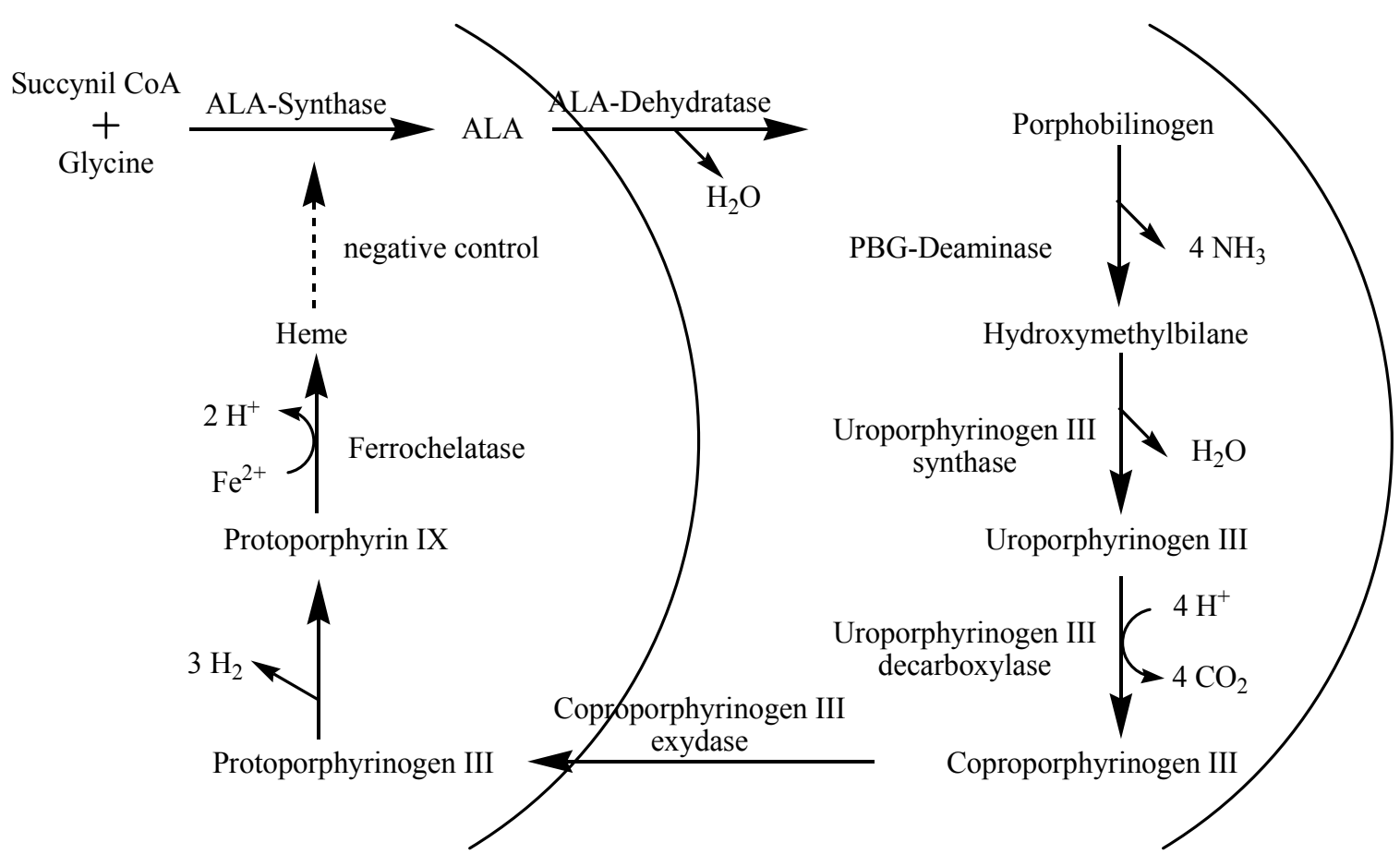<smiles>NCC(=O)CCC(=O)O</smiles>

8

ALA

Figure 9. Molecular structures of methyl aminolevulinate (MAL) and Hexaminolevulinate (HAL).<smiles>COC(=O)CCC(=O)CN</smiles>

9<smiles>CCCCCCOC(=O)CCC(=O)CN</smiles>

MAL 


\subsubsection{Chlorins}

Several photosensitizers evaluated for PDT efficacy are from the chlorin family (cf. Figure 10) and include benzoporphyrin derivative monoacid ring A (BPD-MA, Verteporfin, Visudyne ${ }^{\circledR}, 11$ ), meta-tetra(hydroxyphenyl)chlorin ( $m$-THPC, Foscan $\left.{ }^{\circledR}, 12\right)$, tin ethyl etiopurpurin (SnET2, Rostaporfin, Purlytin $^{\mathrm{TM}}, 13$ ), and $\mathrm{N}$-aspartyl chlorin e6 (NPe6, Talaporfin, Ls11, 14) which is derived from chlorophyll a (15). When compared to porphyrins, the structure of chlorins differs by two extra hydrogens in one pyrrole ring. This structural change leads to a bathochromic shift in the absorption band (640 to $700 \mathrm{~nm}$ ) and gives $\varepsilon_{\max } \sim 40,000 \mathrm{M}^{-1} \mathrm{~cm}^{-1}$.

Figure 10. Examples of chlorins evaluated for PDT use.



11

BPD-MA

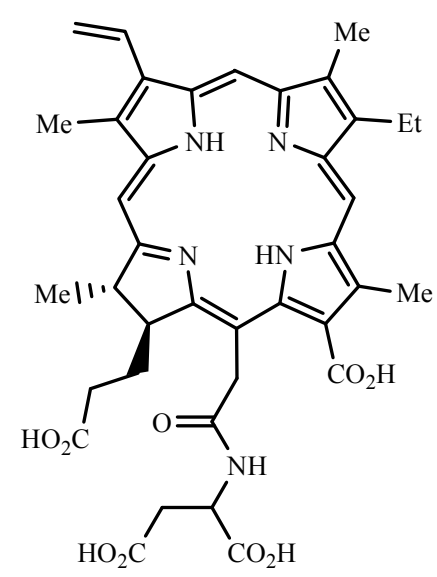

14

NPe6

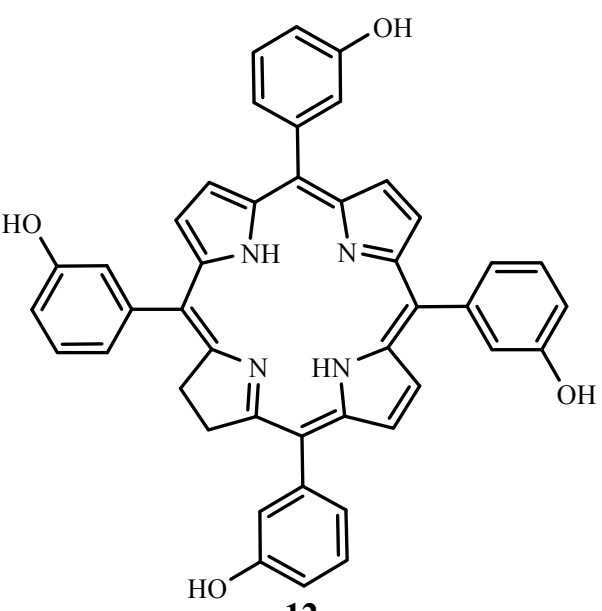

12

$m$-THPC

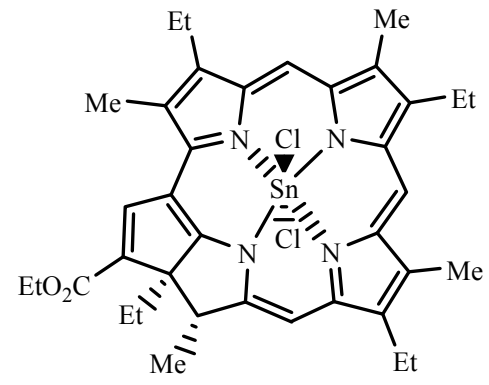

13

SnET2

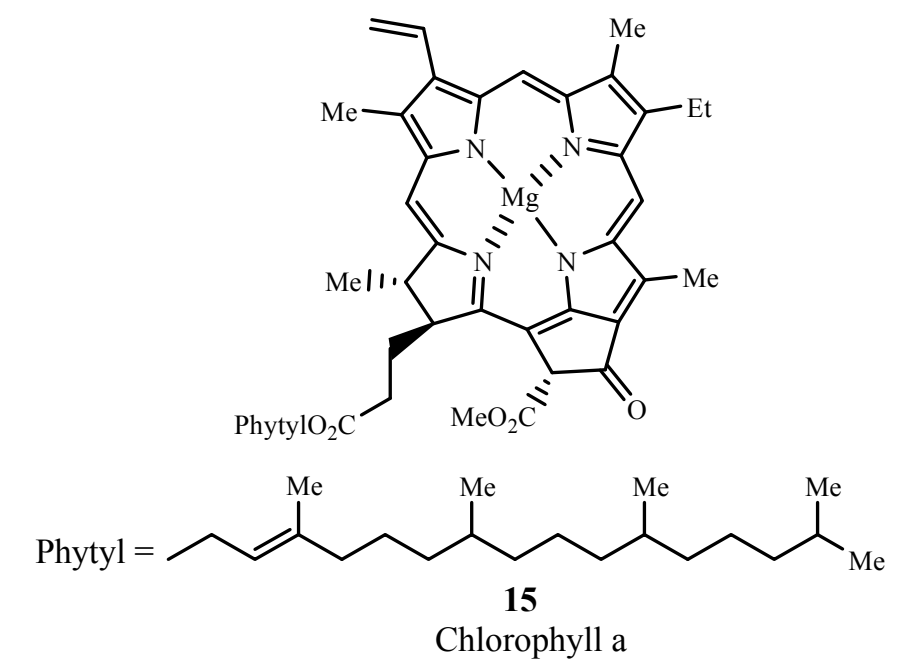

BPD-MA is activated by light at $689 \mathrm{~nm}$ and has a lower time interval of skin phototoxicity than Photofrin $^{\circledR}$, due to rapid plasma and tissue pharmacokinetics which enables faster excretion of the drug from the body [47]. In 1999, US FDA approved the use of BPD-MA as Visudyne ${ }^{\circledR}$ for age-related macular degeneration in ophthalmology [48]. Additionally, a 24-month study of Verteporfin treatment showed improvement in patients with non-melanoma skin cancer [49]. 
$m$-THPC can be prepared by a reduction of one of the pyrrole rings in $m$-THPP, as shown in Figure 11 [2]. PDT treatment of neck and scalp cancer with $m$-THPC was approved in Europe, and the drug was used successfully for treating breast, prostate, and pancreatic cancers [48,50,51]. Light activation at $652 \mathrm{~nm}$ is very effective and only small doses of $m$-THPC are required during treatment. A weakness of $m$-THPC is high skin photosensitivity in some patients.

Figure 11. Formation of meta-tetra(hydroxyphenyl)chlorin (m-THPC) by tosylhydrazine reduction of meta-tetra(hydroxyphenyl)porphyrin ( $m$-THPP).

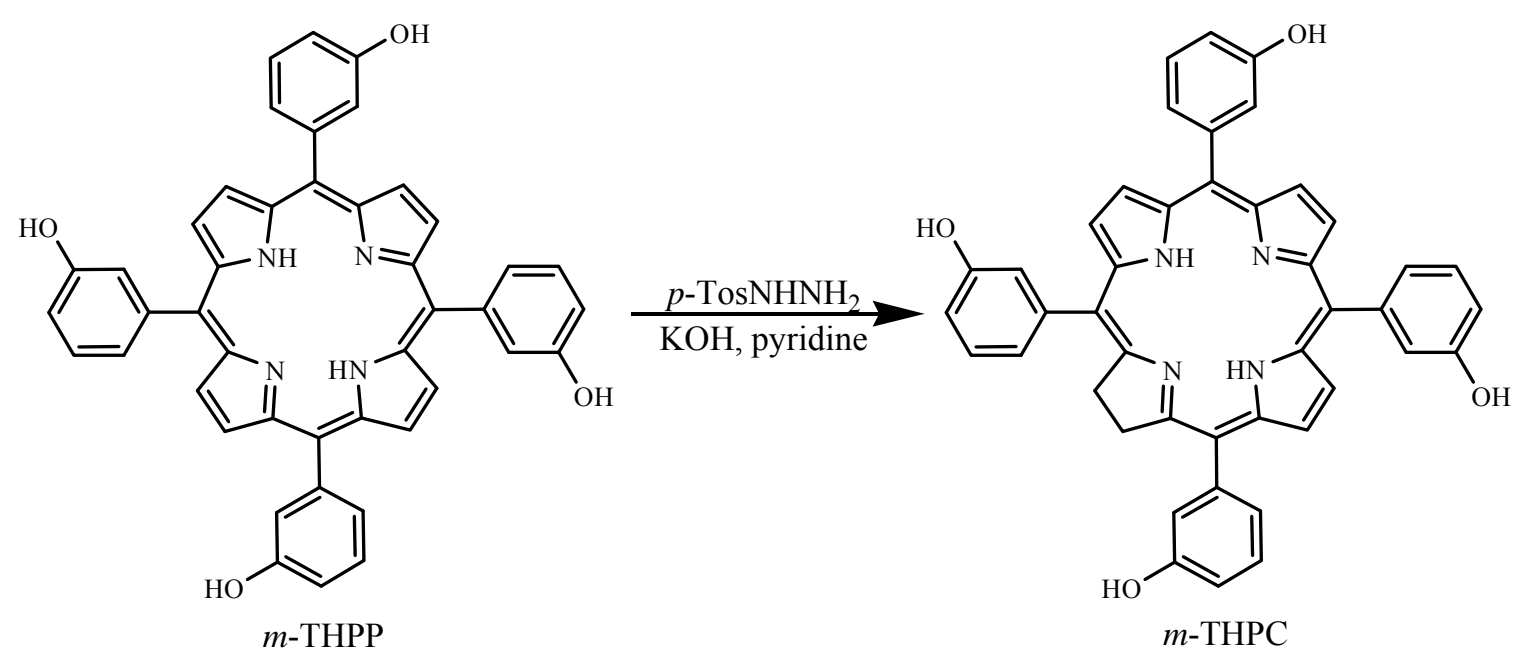

SnET2, under the trademark Purlytin ${ }^{\mathrm{TM}}$, has been evaluated in Phase I/II trials for the treatment of metastatic breast adenocarcinoma, basal cell carcinoma, and Kaposi's sarcoma [52]. This drug has also finished Phase III trials for the treatment of age-related macular degeneration but has not yet been approved by the FDA, due to a requirement of further efficacy and safety assessments [9]. Purlytin ${ }^{\mathrm{TM}}$ is activated at $664 \mathrm{~nm}$ and has deeper tissue penetration than Photofrin ${ }^{\circledR}$. The drawback of the drug is a possibility of dark toxicity and skin photosensitivity.

NPe6 is another photosensitizer that can be irradiated at $664 \mathrm{~nm}$ for potential PDT treatment of fibrosarcoma, liver, brain, and oral cancer, and was approved in Japan in 2003 to treat lung cancer [31,53]. Similar to BPD-MA, NPe6 causes minimal skin photosensitivity, unlike Photofrin ${ }^{\circledR}$.

\subsubsection{Pheophorbides}

Pheophorbides also have two extra hydrogens in one pyrrole unit and they can be derived from chlorophyll. HPPH is 2-(1-hexyloxyethyl)-2-devinyl pyropheophorbide (Photochlor ${ }^{\circledR}$, 16; Figure 12) and absorbs at $665 \mathrm{~nm}$ with $\varepsilon_{\max } \sim 47,000 \mathrm{M}^{-1} \mathrm{~cm}^{-1}$ [54]. HPPH has been approved for use in clinical trials and has undergone Phase I/II trials for esophageal cancer (NCT00060268) [55] and Phase I trials involving basal cell skin cancer (NCT00017485) [56]. HPPH is currently in Phase II trials for lung cancer (NCT00528775) [57] and esophageal cancer at precancerous or early stage conditions (NCT00281736) [58], in Phase I trials for treating dysplasia, carcinoma of the oral cavity, carcinoma of the oropharynx (NCT01140178) [59], and head and neck cancer (NCT00670397) [60], and in phase I/II trials involving Barrett's esophagus (NCT01236443) [61]. 
Figure 12. Molecular structure of 2-(1-hexyloxyethyl)-2-devinyl pyropheophorbide (HPPH).

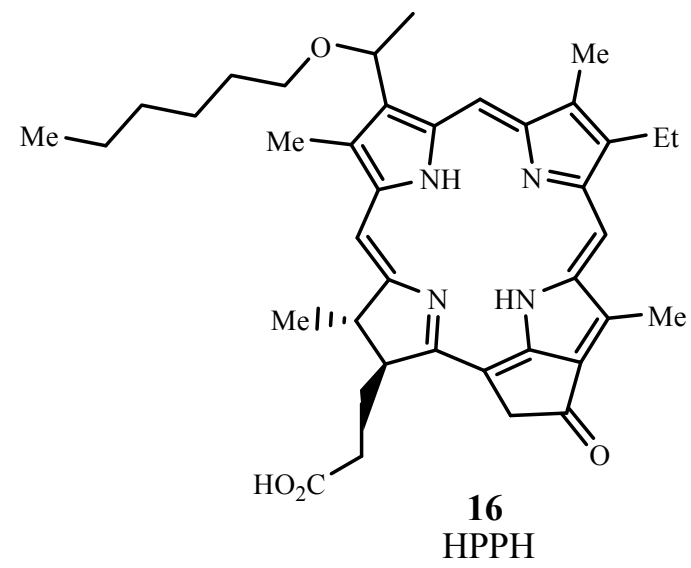

\subsubsection{Bacteriopheophorbides}

Bacteriopheophorbides are similar to bacteriochlorins but their structures have four more hydrogens than the corresponding porphyrins (cf. Figure 13). Generally, the $\lambda_{\max }$ of these sensitizers is red-shifted to $740-800 \mathrm{~nm}$, with $\varepsilon_{\max } \sim 50,000 \mathrm{M}^{-1} \mathrm{~cm}^{-1}$. WST09 (padoporfin, Tookad ${ }^{\circledR}, 17$ ) is derived from bacteriochlorphyll a (18), which is isolated from bacteria. WST09 is activated at $763 \mathrm{~nm}$ and has low skin accumulation with quick drug excretion from the body [62]. This dye sensitizer has been evaluated for treating prostate cancer in Phase II clinical trials (NCT00308919) [63]. The advantages of deeper tissue penetration than Photofrin ${ }^{\circledR}$ and minimum skin photosensitivity render this drug superior to other clinically used photosensitizers to date [52]. A water soluble derivative of WST09 is WST11 (Stakel $\left.{ }^{\circledR}, 19\right)$ and is manufactured by Steba Biotech [64]. Phase I/II (NCT00946881) [65] and Phase II (NCT00707356) [66] trials involving prostate cancer have been completed for WST11 in the US.

Figure 13. Examples of pheophorbide sensitizers for PDT use.

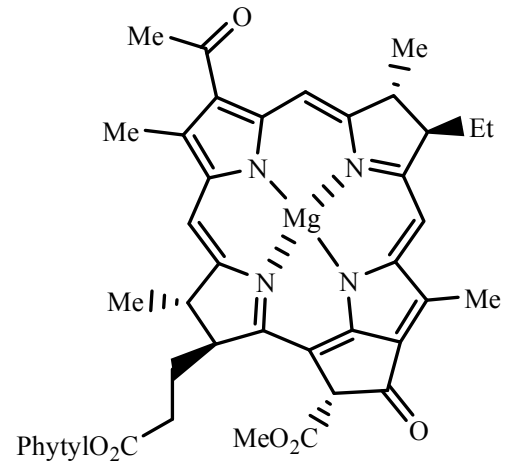

17

Bacteriochlorophyll a

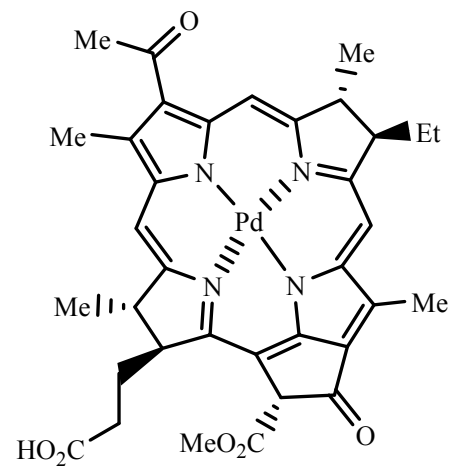

18

WST09

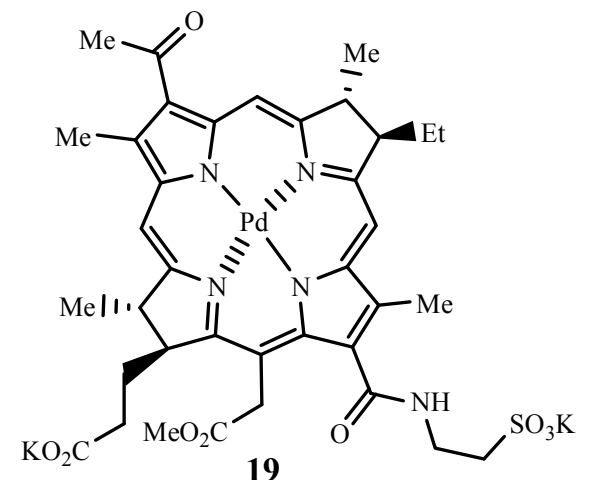

WST11

\subsubsection{Texaphyrins}

Lu-Tex (motexafin lutetium, Lutrin ${ }^{\circledR}, \mathbf{2 0}$; Figure 14) is a texaphyrin, which is a porphyrinoid analog having a pentaaza core. This sensitizer is water soluble and absorbs light at $732 \mathrm{~nm}$ with 
$\varepsilon_{\max } \sim 42,000 \mathrm{M}^{-1} \mathrm{~cm}^{-1}$. The drug Lutrin ${ }^{\circledR}$ has been evaluated in Phase I trials for the treatment of prostate cancer, but requires further studies to confirm efficacy and to improve drug delivery [67]. Lutrin $^{\circledR}$ has undergone Phase I trials for treating cervical cancer (NCT00005808) [68], and has also entered Phase II trials for treatment of breast cancer and malignant melanoma [69]. Lu-Tex, under the trademark name Optrin ${ }^{\circledR}$, is undergoing Phase II trials for the treatment of age-related macular degeneration, and Antrin ${ }^{\circledR}$, also Lu-Tex, is undergoing clinical trials in photoangioplasty to treat peripheral arterial disease and coronary arterial disease [70].

Figure 14. Molecular structure of a texaphyrin sensitizer.

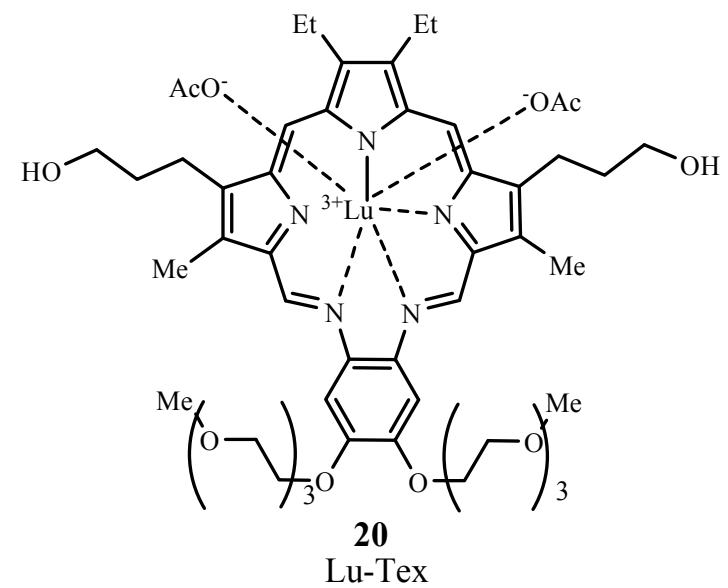

\subsubsection{Phthalocyanines}

Phthalocyanines $(\mathrm{Pc})$ require metal complex formation to exhibit PDT properties because transition metals allow intersystem crossing to occur [71]. Their $\lambda_{\max }$ can be found at $670-700 \mathrm{~nm}$, with $\varepsilon_{\max } \sim 200,000 \mathrm{M}^{-1} \mathrm{~cm}^{-1}$. One specific Pc derivative is aluminum phthalocyanine tetrasulfonate AlPcS4, Photosens, 21; Figure 15) which has $\lambda_{\max }$ at $676 \mathrm{~nm}$. AlPcS4, as Photosens, has been used in Russia to treat stomach, skin, lip, oral, and breast cancer [9]. However, Photosens produces skin phototoxicity for several weeks.

Figure 15. Examples of phthalocyanine PDT sensitizers.

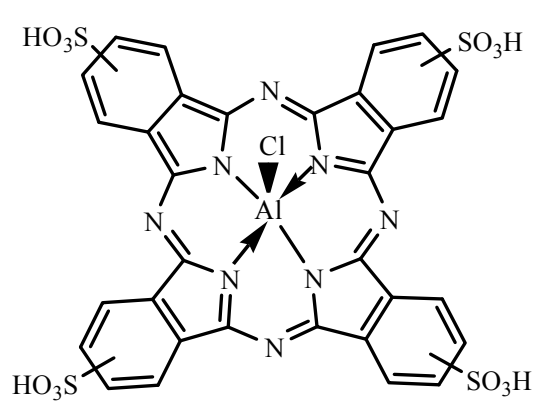

21

AlPcS4

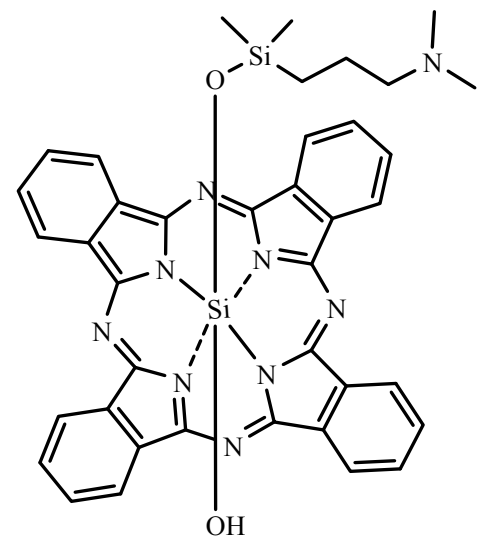

22

$\operatorname{Pc} 4$ 
Silicon phthalocyanine $4(\mathrm{Pc} 4,22)$ is a phthalocyanine that absorbs at $675 \mathrm{~nm}$ and has completed Phase I trials for treating actinic keratosis, Bowen's disease, skin cancer, and State I or II mycosis fungoides (NCT00103246) [72]. In preliminary studies involving cutaneous cancers such as recurrent breast cancer, a complete pharmacokinetic assessment and the maximum tolerated dose were not established [73].

A summary of the properties of clinical photosensitizers covered in this chapter is provided in Table 2 along with $\Phi_{\Delta}$, where available [74-76].

Table 2. Properties of some photosensitizer dyes approved for PDT treatment and used in PDT-related clinical trials.

\begin{tabular}{|c|c|c|c|c|}
\hline Compound & Trademark & $\begin{array}{l}\lambda_{\max }(\mathrm{nm}) \\
\varepsilon_{\max }\left(\mathbf{M}^{-1} \mathbf{c m}^{-1}\right) \\
\end{array}$ & $\boldsymbol{\Phi}_{\Delta}$ & Application \\
\hline Porfimer sodium & Photofrin & $632(3000)$ & 0.89 & $\begin{array}{l}\text { Canada (1993) —-bladder cancer; USA (1995)—esophogeal } \\
\text { cancer; USA (1998)—lung cancer; USA (2003)—Barrett's } \\
\text { esophagus; Japan - cervical cancer; Europe, Canada, } \\
\text { Japan, USA, UK —endobroncheal cancer }\end{array}$ \\
\hline 5-Aminolevulinic acid (ALA) & Levulan & $632(5000)$ & 0.56 & USA (1999)—actinic keratosis \\
\hline Methyl aminolevulinate (MAL) & Metvixia & - & - & USA (2004)—actinic keratosis \\
\hline Hexaminolevulinate (HAL) & Cysview & - & - & USA (2010)_-bladder cancer diagnosis \\
\hline $\begin{array}{l}\text { Benzoporphyrin derivative } \\
\text { monoacid ring A (BPD-MA) }\end{array}$ & Visudine & $689(34,000)$ & 0.84 & USA (1999) — age-related macular degeneration \\
\hline $\begin{array}{l}\text { Meta-tetra(hydroxyphenyl)chlorin } \\
\text { (m-THPC) }\end{array}$ & Foscan & $652(35,000)$ & 0.87 & Europe-neck and head cancer \\
\hline Tin ethyl etiopurpurin & Purlytin & $664(30,000)$ & - & $\begin{array}{l}\text { Clinical trials - breast adenocarcinoma, basal cell } \\
\text { carcinoma, Kaposi's sarcoma, age-related macular } \\
\text { degeneration }\end{array}$ \\
\hline$N$-aspartyl chlorin e6 (NPe6) & $\begin{array}{l}\text { Laserphyrin, } \\
\text { Litx }\end{array}$ & $664(40,000)$ & 0.77 & Japan (2003)-lung cancer \\
\hline $\begin{array}{l}\text { 2-(1-Hexyloxyethyl)-2-devinyl } \\
\text { pyropheophorbide (HPPH) }\end{array}$ & Photochlor & $665(47,000)$ & - & $\begin{array}{l}\text { Clinical trials - esophogeal cancer, basal cell carcinoma, } \\
\text { lung cancer, Barrett's esophagus }\end{array}$ \\
\hline $\begin{array}{l}\text { Palladium bacteriopheophorbide } \\
\text { (WST09) }\end{array}$ & Tookad & $763(88,000)$ & 0.50 & Clinical trials - prostate cancer \\
\hline WST11 & Stakel & - & - & Clinical trials - prostate cancer \\
\hline Motexafin lutetium (Lu-Tex) & $\begin{array}{l}\text { Lutrin, } \\
\text { Optrin, } \\
\text { Antrin }\end{array}$ & $732(42,000)$ & - & $\begin{array}{l}\text { Clinical trials - prostate cancer, age-related macular } \\
\text { degeneration, breast cancer, cervical cancer, arterial } \\
\text { disease }\end{array}$ \\
\hline $\begin{array}{l}\text { Aluminum phthalocyanine } \\
\text { tetrasulfonate (AlPcS4) }\end{array}$ & Photosens & $676(200,000)$ & 0.38 & $\begin{array}{l}\text { Russia (2001) — stomach, skin, lips, oral cavity, tongue, } \\
\text { breast cancer }\end{array}$ \\
\hline Silicon phthalocyanine (Pc4) & - & $675(200,000)$ & - & $\begin{array}{l}\text { Clinical trials — actinic keratosis, Bowen's disease, skin } \\
\text { cancer, mycosis fungoides }\end{array}$ \\
\hline
\end{tabular}

\subsection{Non-Porphyrin Photosensitizers}

Although porphyrinoid structures comprise a majority of photosensitizers, several non-porphyrin chromogens exhibit photodynamic activity. These compounds include anthraquinones, phenothiazines, xanthenes, cyanines, and curcuminoids. 


\subsubsection{Anthraquinones}

Hypericin (23; Figure 16) is a naturally occurring anthraquinone derivative extracted from St. John's wort and is known for generating ROS that target cancer cells. Hypericin absorbs at $590 \mathrm{~nm}$ with $\varepsilon_{\max } \sim 44,000 \mathrm{M}^{-1} \mathrm{~cm}^{-1}$. Clinical trials have been performed to treat squamous cell carcinoma and basal cell carcinoma [77] but the results are unsatisfactory to date. Studies aimed at optimization and enhancement of dosage, drug and light delivery, and preparation of tested area have been undertaken [78].

Figure 16. Example of an anthraquinone PDT sensitizer.<smiles>Cc1cc(O)c2c(c1)C(=C1c3cc(C)cc(O)c3C(=O)c3c(O)cc(O)cc31)c1cc(O)cc(O)c1C2=O</smiles>

\subsubsection{Phenothiazines}

Methylene blue (24; Figure 17) belongs to the phenothiazinium family and absorbs at $666 \mathrm{~nm}$ with $\varepsilon_{\max } \sim 82,000 \mathrm{M}^{-1} \mathrm{~cm}^{-1}$. This sensitizer targets melanoma cells and has positive PDT action against melanoma cell cultures [79]. Clinical PDT treatments using methylene blue include basal cell carcinoma and Kaposi's sarcoma, in vitro testing of adenocarcinoma, bladder carcinoma, and HeLa cervical tumor cells [80]. Clinical trials involving chronic periodontitis have also been completed (NCT01535690) [81]. Another phenothiazinium dye is toluidine blue (25) which is undergoing Phase 2 clinical trials for treating chronic periodontitis (NCT01330082) [82]. Toluidine blue absorbs at $596 \mathrm{~nm}$ and $630 \mathrm{~nm}$ with $\varepsilon_{\max (630 \mathrm{~nm})} \sim 51,000 \mathrm{M}^{-1} \mathrm{~cm}^{-1}[83,84]$.

Figure 17. Examples of phenothiazine PDT sensitizers.<smiles></smiles>

24

Methylene blue<smiles></smiles>

25

Toluidine blue

\subsubsection{Xanthenes}

Rose Bengal (26; Figure 18) is a water soluble xanthene sensitizer that absorbs at $549 \mathrm{~nm}$ with $\varepsilon_{\max } \sim 100,000 \mathrm{M}^{-1} \mathrm{~cm}^{-1}$. This sensitizer is an experimental agent for PDT treatment of breast carcinoma and metastatic melanoma [85]. 4,5-Dibromorhodamine methyl ester (TH 9409, 27) absorbs light at $514 \mathrm{~nm}$ with $\varepsilon_{\max } \sim 100,000 \mathrm{M}^{-1} \mathrm{~cm}^{-1}$. The presence of halogen atoms increases the efficiency 
of intersystem crossing to the triplet state and yields singlet oxygen. This sensitizer has been evaluated for PDT treatment of graft-versus-host disease and it destroys lymphocytes via apoptosis [86,87]. It has also entered clinical trials involving allogeneic stem cell transplantation [9].

Figure 18. Examples of xanthene PDT sensitizers.<smiles>[X]C(=O)c1c(Cl)c(Cl)c(Cl)c(Cl)c1-c1c2cc(I)c(=O)c(I)c-2oc2c(I)c(O)c(I)cc12</smiles>

26

Rose bengal<smiles>CC(=O)c1ccccc1-c1c2ccc(=N)c(Br)c-2oc2c(Br)c(N)ccc12</smiles>

27

TH9402

\subsubsection{Cyanines}

Merocyanine 540 (28; Figure 19) absorbs at $556 \mathrm{~nm}$ with $\varepsilon_{\max } \sim 110,000 \mathrm{M}^{-1} \mathrm{~cm}^{-1}$ and targets leukemia and lymphoma cells [88]. This cyanine sensitizer has been evaluated for PDT in preclinical and in vitro models for treatment of leukemia and neuroblastoma where it produced considerable cellular damage [89].

Figure 19. Example of a merocyanine PDT sensitizer.

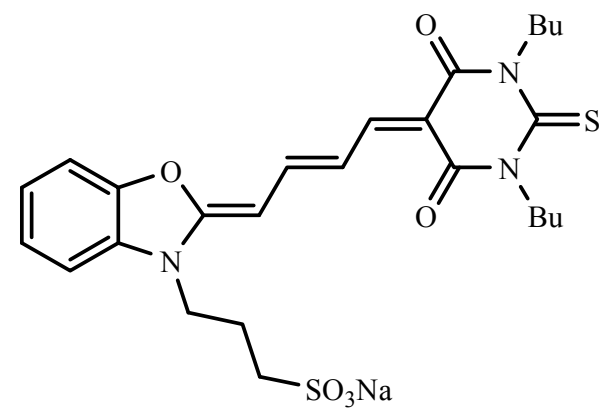

28

Merocyanine 540

\subsubsection{Curcuminoids}

Curcumin (29; Figure 20) is a natural colorant isolated from rhizomas of Curcuma longa $L$ and is a component of turmeric, a cooking spice [90]. Curcumin absorbs at $420 \mathrm{~nm}$ and has $\varepsilon_{\max } \sim 55,000 \mathrm{M}^{-1} \mathrm{~cm}^{-1}$ [91], and has been used in a pilot study as a disinfectant in oral surgery via photodynamic action [92]. This natural dye has been proposed as an agent for destroying bacteria via PDT. 
Figure 20. Example of a curcuminoid PDT sensitizer.<smiles>COc1cc(/C=C/C(=O)/C=C(O)/C=C/c2ccc(O)c(OC)c2)ccc1O</smiles>

29

Curcumin

The non-porphyrin sensitizers and their properties are listed in Table 3. None have received FDA approval for their application areas.

Table 3. Examples of non-porphyrin PDT candidates.

\begin{tabular}{|c|c|c|c|}
\hline Compound & $\lambda_{\max }(\mathrm{nm})$ & $\varepsilon_{\max }\left(M^{-1} \mathrm{~cm}^{-1}\right)$ & Application \\
\hline Hypericin & 590 & 44,000 & squamous cell carcinoma, basal cell carcinoma \\
\hline Methylene blue & 666 & 82,000 & $\begin{array}{l}\text { melanoma, basal cell carcinoma, Kaposi's sarcoma, } \\
\text { chronic periodontitis }\end{array}$ \\
\hline Toluidine blue & 630 & 51,000 & chronic periodontitis \\
\hline Rose bengal & 549 & 100,000 & breast carcinoma, melanoma \\
\hline TH9402 & 514 & 100,000 & graft-versus-host disease \\
\hline Merocyanine 540 & 556 & 110,000 & leukemia, lymphoma \\
\hline Curcumin & 420 & 55,000 & oral disinfectant \\
\hline
\end{tabular}

\section{Conclusions}

Once Photofrin ${ }^{\circledR}$ was approved in Canada as a PDT sensitizer for treating bladder cancer, the development of photosensitizer dyes having improved PDT efficacy and low skin sensitivity became an important undertaking worldwide. However, only a few dye sensitizers, all porphyrinoid compounds, have been approved by regulatory authorities for use in PDT since the early days of Photofrin $^{\circledR}$. Although Photofrin ${ }^{\circledR}$ is known to have the highest $\Phi_{\Delta}$ and approval to treat many more cancer types than any other sensitizer, inconsistencies in its production, prolonged skin sensitivity after treatment completion, and low level of tissue penetration cause Photofrin ${ }^{\circledR}$ to be far from ideal. Interestingly, WST09, due to its production reproducibility, absorption properties for deeper tissue penetration, efficacy in clinical trials, and minimal skin sensitivity has better overall properties. It has not yet been approved for PDT treatments.

Currently, porphyrinoid sensitizers enjoy a few advantages over non-porphyrin sensitizers, including longer $\lambda_{\max }(630-760 \mathrm{~nm})$ and research attention extending well into clinical trials. Non-porphyrin sensitizers have $\lambda_{\max }$ range $\sim 420-670 \mathrm{~nm}$ with the majority of these chromogens having $\lambda_{\max }$ below $600 \mathrm{~nm}$. Most of the non-porphyrins sensitizers have been and are still used in medicine, due to their antibacterial, antiviral, antimicrobial, and staining properties on biological tissues. There is a need for further research to modify these chromogens to extend their absorptions past $700 \mathrm{~nm}$. Additionally, very little is known about the photophysical and pharmacokinetic properties of non-porphyrin sensitizers reported in this review. Additional preclinical studies need to be 
undertaken to determine optimal delivery methods, potency, irradiation source, and accumulation in and removal from post-treatment.

\section{Acknowledgements}

The authors thank the Fiber and Polymer Science program at North Carolina State University for supporting this work.

\section{References}

1. Roelandts, R. The history of phototherapy: Something new under the sun? J. Am. Acad. Dermatol. 2002, 46, 926-930.

2. Bonnett, R. Photosensitizers of the porphyrin and phthalocyanine series for photodynamic therapy. Chem. Soc. Rev. 1995, 24, 19-33.

3. Gambichler, T.; Breuckmann, F.B.S.; Altmeyer, P.; Kreuter, A. Narrowband UVB phototherapy in skin conditions beyond psoriasis. J. Am. Acad. Dermatol. 2005, 52, 660-670.

4. Paus, S.; Schmidt-Hubsch, T.; Wullner, U.; Vogel, A.; Klockgether, T.; Abele, M. Bright light therapy in Parkinson's disease: A pilot study. Mov. Disord. 2007, 22, 1495-1498.

5. Wainwright, M. Photodynamic therapy-from dyestuffs to high-tech clinical practice. Rev. Prog. Color. 2004, 34, 95-109.

6. Ledo, E.; Ledo, A. Phototherapy, photochemotherapy, and photodynamic therapy: Unapproved uses or indications. Clin. Dermatol. 2000, 18, 77-86.

7. Bamfield, P. Chromic Phenomena: Technological Applications of Colour Chemistry; The Royal Society of Chemistry: Cambridge, UK, 2001.

8. MacDonald, I.J.; Dougherty, T.J. Basic principles of photodynamic therapy. J. Porphyr. Phthalocyanines 2001, 5, 105-129.

9. Zimcik, P.; Miletin, M. Photodynamic Therapy. In Dyes and Pigments: New Research; Lang, A.R., Ed.; Nova Science Publishers: New York, NY, USA, 2008.

10. Dongen, G.A.M.S.V.; Visser, G.W.M.; Vrouenraets, M.B. Photosensitizer-antibody conjugates for detection and therapy of cancer. Adv. Drug Delivery Rev. 2004, 56, 31-52.

11. Moan, J.; Peng, Q. An Outline Of The History of PDT. In Photodynamic Therapy; Patrice, T., Ed.; Royal Society of Chemistry: Cambridge, UK, 2003.

12. Moor, A.C.E.; Ortel, B.; Hasan, T. Mechanisms of Photodynamic Therapy. In Photodynamic Therapy; Patrice, T., Ed.; Royal Society of Chemistry: Cambridge, UK, 2003.

13. Sternberg, E.D.; Dolphin, D.; Bruckner, C. Porphyrin-based photosensitizers for use in photodynamic therapy. Tetrahedron 1998, 54, 4151-4202.

14. Bellnier, D.A.; Greco, W.R.; Loewen, G.M.; Nava, H.; Oseroff, A.R.; Pandey, R.K.; Tsuchida, T.; Dougherty, T.J. Population pharmacokinetics of the photodynamic therapy agent 2-[1-hexyloxyethyl]-2-devinyl pyropheophorbide-a in cancer patients. Cancer Res. 2003, 63, 1806-1813.

15. Evensen, J.F. The use of porphyrin and non-ionizing radiation for treatment of cancer. Acta Oncol. 1995, 34, 1103-1110. 
16. Hatz, S.; Lambert, J.D.C.; Ogilby, P.R. Measuring the lifetime of singlet oxygen in a single cell: Addressing the issue of cell viability. Photochem. Photobiol. Sci. 2007, 6, 1106-1116.

17. Henderson, B.W.; Dougherty, T.J. How does photodynamic therapy work? Photochem. Photobiol. 1992, 55, 145-157.

18. Maiya, B.G. Photodynamic therapy (PDT). Resonance 2000, 5, 6-18.

19. Chowdhary, R.K.; Sharif, I.; Chansarkar, N.; Dolphin, D. Correlation of photosensitizer delivery to lipoproteins and efficacy in tumor and arthritis mouse models; comparison of lipid-based and Pluronic ${ }^{\circledR}$ P123 formulations. J. Pharm. Pharm. Sci. 2003, 6, 198-204.

20. Jori, G.; Reddi, E. The role of lipoproteins in the delivery of tumor-targeting photosensitizers. Int. J. Biochem. 1993, 25, 1369-1375.

21. Stables, G.I.; Ash, D.V. Photodynamic therapy. Cancer Treat. Rev. 1995, 21, 311-323.

22. Korbelik, M. Low density lipoprotein receptor pathway in the delivery of Photofrin: How much is it relevant for selective accumulation of the photosensitizer in tumors? J. Photochem. Photobiol. B 1992, 12, 107-113.

23. Vicente, M.G.H. Porphyrin-based sensitizers in the detection and treatment of cancer: Recent progress. Curr. Med. Chem. Anti-Cancer Agents 2001, 1, 175-194.

24. Malik, Z.; Amit, I.; Rothmann, C. Subcellular localization of sulfonated tetraphenyl porphines in colon carcinoma cells by spectrally resolved imaging. Photochem. Photobiol. 1997, 65, 389-396.

25. Woodburn, K.W.; Vardaxis, N.J.; Hill, J.S.; Kaye, A.H.; Phillips, D.R. Subcellular localization of porphyrins using confocal laser scanning microscopy. Photochem. Photobiol. 1991, 54, 725-732.

26. Jori, G. Tumor photosensitizers: Approaches to enhance the selectivity and efficiency of photodynamic therapy. J. Photochem. Photobiol. B 1996, 36, 87-93.

27. Stapleton, M.; Rhodes, L.E. Photosensitizers for photodynamic therapy of cutaneous disease. J. Dermatol. Treat. 2003, 14, 107-112.

28. Labbe, R.F.; Nishida, G. A new method of hemin isolation. Biochim. Biophys. Acta 1957, $26,437$.

29. Kessel, D.; Thompson, P.; Musselman, B.; Chang, C.K. Probing the structure and stability of the tumor-localizing derivative of hematoporphyrin by reductive cleavage with $\mathrm{LiAlH}_{4}$. Cancer Res. 1987, 47, 4642-4645.

30. Pushpan, S.K.; Venkatraman, S.; Anand, V.G.; Sankar, J.; Parmeswaran, D.; Ganesan, S.; Chandrashekar, T.K. Porphyrins in photodynamic therapy-A search for ideal photosensitizers. Curr. Med. Chem. Anti-Cancer Agents 2002, 2, 187-207.

31. Usuda, J.; Kato, H.; Okunaka, T.; Furukawa, K.; Tsutsi, H.; Yamada, K.; Suga, Y.; Honda, H.; Nagatsuka, Y.; Ohira, T.; Tsuboi, M.; Hirano, T. Photodynamic therapy (PDT) for lung cancers. J. Thorac. Oncol. 2006, 1, 489-493.

32. Hage, R.; Ferreira, J.; Bagnato, V.S.; Vollet-Filho, J.D.; Plapler, H. Pharmacokinetics of photogem using fluorescence spectroscopy in dimethylhydrazine-inducedmurine colorectal carcinoma. Int. J. Photoenergy 2012, 2012, 1-8.

33. Trindade, F.Z.; Pavarina, A.C.; Ribeiro, A.P.D.; Bagnato, V.S.; Vergani, C.E.; Souza Costa, C.A. Toxicity of photodynamic therapy with LED associated to Photogem ${ }^{\mathbb{B}}$ : An in vivo study. Lasers Mes Sci 2012, 27, 403-411. 
34. Benes, J.; Pouckova, P.; Zeman, J.; Zadinova, M.; Sunka, P.; Lukes, P.; Kolarova, H. Effects of tandem shock waves combined with photosan and cytostatics on the growth of tumours. Folia Biol. 2011, 57, 255-260.

35. Santoro, O.; Bandieramonte, G.; Melloni, E.; Marchesini, R.; Zunino, F.; Lepera, P.; de Palo, G. Photodynamic therapy by topical meso-tetraphenylporphinesulfonate tetrasodium salt administration in superficial basal cell carcinoma. Cancer Res. 1990, 50, 4501-4503.

36. Dougherty, T.J. An update on photodynamic therapy. J. Clin. Laser Med. Surg. 2002, 20, 3-7.

37. Batlle, A.M.D.C. Porphyrins, porphyrias, cancer and photodynamic therapy-A model for carcinogenesis. J. Photochem. Photobiol. B 1993, 20, 5-22.

38. Morton, C.A.; Brown, S.B.; Collins, S.; Ibbotson, S.; Jenkinson, H.; Kurwa, H.; Langmack, K.; McKenna, K.; Moseley, H.; Pearse, A.D.; Stringer, M.; Taylor, D.K.; Wong, G.; Rhodes, L.E. Guidelines for topical photodynamic therapy: Report of a workshop of the British Photodermatology Group. Br. J. Dermatol. 2002, 146, 552-567.

39. Peng, Q.; Berg, K.; Moan, J.; Kongshaug, M.; Nesland, J.M. 5-Aminolevulinic acid-based photodynamic therapy: Principles and experimental research. Photochem. Photobiol. 1997, 65, 235-251.

40. U.S. Food and Drug Administration, Center for Drug Evaluation and Research. Metvixia NDA 21-415 approval letter, 25 May 2004; Retrieved 5 January 5 2013. Available online: http:// www.accessdata.fda.gov/drugsatfda_docs/nda/2004/021415s000_Metvixia_Aprov.pdf (accessed on 28 February 2013).

41. Gilchrest, B.A. Photodynamic Therapy and Selected Off-label Uses. In Proceedings of the Winter Clinical Dermatology Conference; Tuleya, S., Ed.; HMP Communications, LLC: Kohala Coast, HI, USA, 2010; pp. 10-12.

42. PhotoCure. A Double Blinded, Prospective, Randomized, Vehicle Controlled Multi-center Study of Photodynamic Therapy With Visonac ${ }^{\circledR}$ Cream in Patients with Acne Vulgaris. In ClinicalTrials.gov [Internet]. Bethesda (MD): National Library of Medicine (US); Available online: http://clinicaltrials.gov/show/NCT01347879 NLM Identifier: NCT01347879 (accessed on 6 January 2013)

43. U.S. Food and Drug Administration, Center for Drug Evaluation and Research. Cysview NDA 22555 approval letter, 31 March 2010; Retrieved 5 January 2013. Available online: http://www.accessdata.fda.gov/drugsatfda_docs/appletter/2010/022555s0001tr.pdf (accessed on 28 February 2013).

44. Furre, I.E.; Shahzidi, S.; Luksiene, Z.; Moller, M.T.N.; Borgen, E.; Morgan, J.; Tkacz-Stachowska, K.; Nesland, J.M.; Peng, Q. Targeting PBR by hexaminolevulinate-mediated photodynamic therapy induces apoptosis through translocation of apoptosis-inducing factor in human leukemia cells. Cancer Res. 2005, 65, 11051-11060.

45. PhotoCure. Dose-finding Study of Hexaminolevulinate (HAL) Photodynamic Therapy (PDT) to Treat Cervical Neoplasia. In ClinicalTrials.gov [Internet]. Bethesda (MD): National Library of Medicine (US); Available online: http://clinicaltrials.gov/show/NCT01256424 NLM Identifier: NCT01256424 (accessed on 5 January 2012).

46. Oslo University Hospital. Treatment of Female Genital Erosive Lichen Planus(GELP) with Hexaminolevulinate PDT. In ClinicalTrials.gov [Internet]. Bethesda (MD): National Library of 
Medicine (US); Available online: http://clinicaltrials.gov/show/NCT01282515 NLM Identifier: NCT01282515 (accessed on 6 January 2012).

47. Fingar, V.H.; Kik, P.K.; Haydon, P.S.; Cerrito, P.B.; Tseng, M.; Abang, E.; Wieman, T.J. Analysis of actue vascular damage after photodynamic therapy using benzoporphyrin derivative (BPD). Br. J. Cancer 1999, 79, 1702-1708.

48. Rousset, N.; Bourre, L.; Thibaud, S. Sensitizers in Photodynamic Therapy. In Photodynamic Therapy; Patrice, T., Ed.; Royal Society of Chemistry: Cambridge, UK, 2003.

49. Lui, H.; Hobbs, L.; Tope, W.D.; Lee, P.K.; Elmets, C.; Provost, N.; Chan, A.; Neyndorff, H.; Su, X.Y.; Jain, H.; Hamzavi, I.; McLean, D.; Bissonnette, R. Photodynamic therapy of multiple nonmelanoma skin cancers with verteporfin and red light-emitting diodes. Arch. Dermatol. 2004, 140, 26-32.

50. Triesscheijn, M.; Ruevekamp, M.; Aalders, M.; Baas, P.; Stewart, F.A. Outcome of mTHPC mediated photodynamic therapy is primarily determined by the vascular response. Photochem. Photobiol. 2005, 81, 1161-1167.

51. Dolmans, D.; Fukumura, D.; Jain, R.K. Photodynamic therapy for cancer. Nat. Rev. Cancer 2003, $5,380-387$.

52. O’Connor, A.E.; Gallagher, W.M.; Byrne, A.T. Porphyrin and nonporphyrin photosensitizers in oncology: Preclinical and clinical advances in photodynamic therapy. Photochem. Photobiol. 2009, 85, 1053-1074.

53. Kobayashi, W.; Liu, Q.; Nakagawa, H.; Sakaki, H.; Teh, B.; Matsumiya, T.; Yoshida, H.; Imaizumi, T.; Satoh, K.; Kimura, H. Photodynamic therapy with mono-L-aspartyl chlorin e6 can cause necrosis of squamous cell carcinoma of tongue: Experimental study on an animal model of nude mouse. Oral Oncol. 2006, 42, 46-50.

54. Lobel, J.; MacDonald, I.J.; Ciesielski, M.J.; Barone, T.; Potter, W.R.; Pollina, J.; Plunkett, R.J.; Fenstermaker, R.A.; Dougherty, T.J. 2-[1-Hexyloxyethyl]-2-Devinyl Pyropheophorbide-a $(\mathrm{HPPH})$ in a nude rat glioma model: Implications for photodynamic therapy. Lasers Surg. Med. 2001, 29, 397-405.

55. Roswell Park Cancer Institute. Photodynamic Therapy using HPPH in Treating Patients with Obstructive Esophageal Tumors. In ClinicalTrials.gov [Internet]. Bethesda (MD): National Library of Medicine (US); Available online: http://clinicaltrials.gov/show/NCT00060268 NLM Identifier: NCT00060268 (accessed on 5 January 2013).

56. Roswell Park Cancer Institute. Photodynamic Therapy in Treating Patients with Basal Cell Skin Cancer. In ClinicalTrials.gov [Internet]. Bethesda (MD): National Library of Medicine (US); Available online: http://clinicaltrials.gov/show/NCT00017485 NLM Identifier: NCT00017485 (accessed on 5 January 2013).

57. Roswell Park Cancer Institute. Photodynamic Therapy using HPPH in Treating Patients with Advanced Non-Small Cell Lung Cancer That Blocks the Air Passages. In ClinicalTrials.gov [Internet]. Bethesda (MD): National Library of Medicine (US); Available online: http://clinicaltrials.gov/show/NCT00528775 NLM Identifier: NCT00528775 (accessed on 5 January 2013). 
58. Roswell Park Cancer Institute. Photodynamic Therapy in Treating Patients with Precancerous Esophageal Conditions or Early Stage Esophageal Cancer. In ClinicalTrials.gov [Internet]. Bethesda (MD): National Library of Medicine (US); Available online: http://clinicaltrials.gov/ show/NCT00281736 NLM Identifier: NCT00281736 (accessed on 5 January 2013).

59. Roswell Park Cancer Institute. A Trial of Photodynamic Therapy with HPPH for Treatment of Dysplasia, Carcinoma in Situ and T1 Carcinoma of the Oral Cavity and/or Oropharynx. In ClinicalTrials.gov [Internet]. Bethesda (MD): National Library of Medicine (US); Available online: http://clinicaltrials.gov/show/NCT01140178 NLM Identifier: NCT01140178 (accessed on 5 January 2013).

60. Roswell Park Cancer Institute. Photodynamic Therapy using HPPH in Treating Patients with Recurrent Dysplasia, Carcinoma in Situ, or Stage I Oral Cavity Cancer. In ClinicalTrials.gov [Internet]. Bethesda (MD): National Library of Medicine (US); Available online: http://clinicaltrials.gov/show/NCT00670397 NLM Identifier: NCT00670397 (accessed on 5 January 2013).

61. Roswell Park Cancer Institute. Study of Photodynamic Therapy (PDT) using HPPH in Barrett's Esophagus. In ClinicalTrials.gov [Internet]. Bethesda (MD): National Library of Medicine (US); Available online: http://clinicaltrials.gov/show/NCT01236443 NLM Identifier: NCT01236443 (accessed on 6 January 2013).

62. Brun, P.H.; DeGroot, J.L.; Dickson, E.F.G.; Farahani, M.; Pottier, R.H. Determination of the in vivo pharmacokinetics of palladium-bacteriopheophorbide (WST09) in EMT6 tumor-bearing $\mathrm{Balb} / \mathrm{c}$ mice using graphite furnace atomic absorption spectroscopy. Photochem. Photobiol. Sci. 2004, 3, 1006-1010.

63. STEBA France. Study of Photodynamic Therapy in Patients with Prostate Cancer Following Radiation Therapy. In ClinicalTrials.gov [Internet]. Bethesda (MD): National Library of Medicine (US); Available online: http://clinicaltrials.gov/show/NCT00308919 NLM Identifier: NCT00308919 (accessed on 5 January 2013).

64. Chevalier, S.; Anidjar, M.; Scarlata, E.; Hamel, L.; Scherz, A.; Ficheux, H.; Borenstein, N.; Fiette, L.; Elhilali, M. Preclinical study of the novel vascular occluding agent, WST11, for photodynamic therapy of the canine prostate. J. Urol. 2011, 196, 302-309.

65. Steba Biotech, S.A. Safety and Tolerability Study using WST11 in Patients with Localized Prostate Cancer. In ClinicalTrials.gov [Internet]. Bethesda (MD): National Library of Medicine (US); Available online: http://clinicaltrials.gov/show/NCT00946881 NLM Identifier: NCT00946881 (accessed on 6 January 2013).

66. Steba Biotech, S.A. Study of WST11 in Patients with Localized Prostate Cancer. In ClinicalTrials.gov [Internet]. Bethesda (MD): National Library of Medicine (US); Available online: http://clinicaltrials.gov/show/NCT00707356 NLM Identifier: NCT00707356 (accessed on 6 January 2013).

67. Patel, H.; Mick, R.; Finlay, J.C.; Zhu, T.C.; Rickter, E.; Cengel, K.A.; Malkowicz, S.B.; Hahn, S.M.; Busch, T.M. Motexafin lutetium-photodynamic therapy of prostate cancer: Short- and long-term effects of prostate-specific antigen. Clin. Cancer Res. 2008, 14, 4869-4876. 
68. University of Pittsburgh. Photodynamic Therapy using Lutetium Texaphyrin in Treating Patients with Cervical Intraepithelial Neoplasia. In ClinicalTrials.gov [Internet]. Bethesda (MD): National Library of Medicine (US); Available online: http://clinicaltrials.gov/show/NCT00005808 NLM Identifier: NCT00005808 (accessed on 5 January 2013).

69. Josefsen, L.B.; Boyle, R.W. Photodynamic therapy and the development of metal-based photosensitizers. Met. Based Drugs 2008, 2008, 1-24.

70. Mody, T.D.; Sessler, J.L. Texaphyrins: A new approach to drug development. J. Porphyr. Phthalocyanines 2001, 5, 134-142.

71. Ali, H.; Lier, J.E.V. Metal complex as photo- and radiosensitizers. Chem. Rev. 1999, 99, 2379-2450.

72. Case Comprehensive Cancer Center. Photodynamic Therapy using Silicon Phthalocyanine 4 in Treating Patients with Actinic Keratosis, Bowen's Disease, Skin Cancer, or Stage I or Stage II Mycosis Fungoides. In ClinicalTrials.gov [Internet]. Bethesda (MD): National Library of Medicine (US); Available online: http://clinicaltrials.gov/show/NCT00103246 NLM Identifier: NCT00103246 (accessed on 6 January 2013).

73. Kinsella, T.J.; Baron, E.D.; Colussi, V.C.; Cooper, K.D.; Hoppel, C.L.; Ingalls, S.T.; Kenney, M.E.; Li, X.; Oleinick, N.L.; Stevens, S.R.; et al. Preliminary clinical and pharmacologic investigation of photodynamic therapy with the silicon phthalocyanine photosensitizer Pc 4 for primary or metastatic cutaneous cancers. Front. Oncol. 2011, 1, 1-6.

74. Fernandez, J.M.; Bilgin, M.D.; Grossweiner, L.I. Singlet oxygen generation by photodynamic agents. J. Photochem. Photobiol. B 1997, 37, 131-140.

75. Vakrat-Haglili, Y.; Weiner, L.; Brumfeld, V.; Brandis, A.; Salomon, Y.; Mcllroy, B.; Wilson, B.C.; Pawlak, A.; Rozanowska, M.; Sarna, T.; Scherz, A. The microenvironment effect on the generation of reactive oxygen species by pd-bacteriopheophorbide. J. Am. Chem. Soc. 2005, 127, 6487-6497.

76. Plaetzer, K.; Krammer, B.; Berlanda, J.; Berr, F.; Kiesslich, T. Photophysics and photochemistry of photodynamic therapy: Fundamental aspects. Lasers Med. Sci. 2009, 24, 259-268.

77. Sanovic, R.; Krammer, B.; Grumboeck, S.; Verwanger, T. Time-resolved gene expression profiling of human squamous cell carcinoma cells during the apoptosis process induced by photodynamic treatment with hypericin. Int. J. Oncol. 2009, 35, 921-939.

78. Kacerovska, D.; Pizinger, K.; Majer, F.; Smid, F. Photodynamic therapy of nonmelanoma skin cancer with topical hypericum perforatum extract-a pilot study. Photochem. Photobiol. 2008, 84, 779-785.

79. Chen, Y.; Zheng, W.; Li, Y.; Zhong, J.; Ji, J.; Shen, P. Apoptosis induced by methylene-blue-mediated photodynamic therapy in melanolmas and the involvement of mitochondrial dysfunction revealed by proteomics. Cancer Sci. 2008, 99, 2019-2027.

80. Lu, Y.; Jiao, R.; Chen, X.; Zhong, J.; Ji, J.; Shen, P. Methylene blue-mediated photodynamic therapy induces mitochondria-dependent apoptosis in HeLa cell. J. Cell. Biochem. 2008, 105, 1451-1460. 
81. Escola Bahiana de Medicina e Saude Publica. Photodynamic Therapy Associated with Full-mouth Ultrasonic Debridement in the Treatment of Severe Chronic Periodontitis. In ClinicalTrials.gov [Internet]. Bethesda (MD): National Library of Medicine (US); Available online: http://clinicaltrials.gov/show/NCT01535690 NLM Identifier: NCT01535690 (accessed on 3 January 2013).

82. Tehran University of Medical Sciences. Adjunctive Photodynamic Therapy in the Treatment of Chronic Periodontitis. In ClinicalTrials.gov [Internet]. Bethesda (MD): National Library of Medicine (US); Available online: http://clinicaltrials.gov/show/NCT01330082 NLM Identifier: NCT01330082 (accessed on 5 January 2013).

83. Jebaramya, J.; Ilanchelian, M.; Prabahar, S. Spectral studies of toluidine blue O in the presence of sodium dodecyl sulfate. Dig. J. Nanomater. Biostruct. 2009, 4, 789-797.

84. Tanaka, M.; Kinoshita, M.; Yoshihara, Y.; Shinomiya, N.; Seki, S.; Nemoto, K.; Hirayama, T.; Dai, T.; Huang, L.; Hamblin, M.; Morimoto, Y. Optimal photosensitizers for photodynamic therapy of infections should kill bacteria but spare neutrophils. Photochem. Photobiol. 2012, 88, 227-232.

85. Mousavi, S.H.; Tavakkol-Afshari, J.; Brook, A.; Jafari-Anarkooli, I. Direct toxicity of rose bengal in MCF-7 cell line: Roloe of apoptosis. Food Chem. Toxicol. 2009, 47, 855-859.

86. Guimond, M.; Balassy, A.; Barrette, M.; Brochu, S.; Perreault, C.; Roy, D.C. P-glycoprotein targeting: A unique strategy to selectively eliminate immunoreactive T cells. Blood 2002, 100, 375-382.

87. Broady, R.; Yu, J.; Levings, M.K. Pro-tolerogenic effects of photodynamic therapy with TH9402 on dendritic cells. J. Clin. Apheresis 2008, 23, 82-91.

88. Tsujino, I.; Miyagi, K.; Sampson, R.W.; Sieber, F. Potentiation of the antitumor effect of merocyanine 540-mediated photodynamic therapy by amifostine and amphotericin B. Photochem. Photobiol. 2006, 82, 458-465.

89. Delaey, E.; van Laar, F.; de Vos, D.; Kamuhabwa, A.; Jacobs, P.; de Witte, P. A comparative study of the photosensitizing characteristics of some cyanine dyes. J. Photochem. Photobiol. B 2000, 55, 27-36.

90. Dovigo, L.N.; Pavarina, A.C.; Ribeiro, A.P.D.; Brunetti, I.L.; Costa, C.A.D. S.; Jacomassi, D.P.; Bagnato, V.S.; Kurachi, C. Investigation of the photodynamic effects of curcumin agains Candida albicans. Photochem. Photobiol. 2011, 87, 895-903.

91. Waranyoupalin, R.; Wongnawa, S.; Wongnawa, M.; Pakawatchai, C.; Panichayupakaranant, P.; Sherdshoopongse, P. Studies on complex formation between curcumin and $\mathrm{Hg}$ (II) ion by spectrophotometric method: A new approach to overcome peak overlap. Cent. Eur. J. Chem. 2009, 7, 388-394.

92. Araujo, N.C.; Fontana, C.R.; Gerbi, M.E.M.; Bagnato, V.S. Overall-mouth disinfection by photodynamic therapy using curcumin. Photomed. Laser Surg. 2012, 30, 96-101.

(C) 2013 by the authors; licensee MDPI, Basel, Switzerland. This article is an open access article distributed under the terms and conditions of the Creative Commons Attribution license (http://creativecommons.org/licenses/by/3.0/). 